\title{
Would a Consumption Tax Be Fairer Than an Income Tax?
}

\author{
Alvin Warren ${ }^{\dagger}$
}

The consensus that culminated in the adoption of the Sixteenth Amendment and the enactment of the federal income tax has been under attack in both academic and professional circles for several years. The view that consumption, not income, is the fairer basis on which to levy a progressive personal tax can be found in recent law reviews, ${ }^{1}$ economic journals, ${ }^{2}$ and Treasury Department study papers, ${ }^{3}$ as well as the reports of commissions created to review the tax structures of the United Kingdom and Sweden. ${ }^{*}$ And signifying the growing respectability of what is a very old idea among economists, ${ }^{\overline{5}}$ the Brookings Institution has recently sponsored a conference of experts to review the theoretical and practical considerations involved in a personal tax on

† Professor of Law, University of Pennsylvania Law School; Visiting Professor of Law, Harvard Law School, 1979-80.

1. The seminal work is Andrews, $A$ Consumption-Type or Cash Flow Personal Income Tax, 87 HaRv. L. Rev. 1113 (1974) [hereinafter cited as Consumption Tax]; see Warren, Fairness and a Consumption-Type or Cash Flow Personal Income Tax, 88 Harv. L. REv. 931 (1975) (criticizing Andrews' argument); Andrews, Fairness and the Choice Between a Consumplion-Type and an Accretion-Type Personal Income Tax: A Reply to Professor Warren, 88 HaRv. L. REv. 947 (1975) [hereinafter cited as Andrews' Reply]; Klein, Timing in Personal Taxation, 6 J. Legal Stud. 461 (1977).

2. See, e.g., Boskin, Taxation, Saving, and the Rate of Interest, $86 \mathrm{~J}$. Ponitical Econ. S3 (1978); Bradford \& Toder, Consumption vs. Income Base Taxes: The Argument on Grounds of Equity and Simplicily, 69 NAT'L TAX A. Proc. 25 (1976); Feldstein, The Welfare Cost of Capital Income Taxation, 86 J. Political Econ. S29, S37-S39 (1978).

3. See, e.g., U.S. Dep't of the Treasury, Blueprints for Basic Tax Reform 21-52, 113-44 (1977) [hereinafter cited as Blueprints]; P. Mireszrowski, The Cash Flow Version of AN Expenditure TAx 3.4 (May 1977) (U.S. Dep't of Treasury, Office of Tax Analysis, OTA Paper 26).

4. See, e.g., Institute for Fiscal Studifs, The Structure and Reform of Direct Taxation 33-34 (1978) (U.K.) [hereinafter cited as the Meade Report]; S. Lodin, Progressive Expenditure TAx-AN AlTerNative? (1978) (report of the 1972 [Swedish] Government Commission on Taxation) (translated into English in 1978).

5. In addition to the works cited in notes 1-4, supra, support for consumption taxation can be found in T. Hobbes, Leviathan 226 (M. Oakeshott ed. 1960); J.S. Mill, Principles of Political Economy bk. V, ch. I, $\$ 4$ (Laughlin ed. 1898). In more recent times, the most comprehensive treatment is found in N. KaLdoR, AN Expenditure TAX (1955). For further discussion, see I. Fisher \& H. Fisher, Constructive Income Taxation 3-17 (1942); W. Vickrey, Agenda for Progrissive Taxation 329-61 (1947); Friedman, The Spendings Tax as a Wartime Fiscal Measure, 33 AM. Econ. REv. 50 (1943); Marshall, The Equitable Distribution of Taxation (1917) in Memorials of Alfred Marshall 347, 350-51 (A. Pigou ed. 1925). 
consumption. ${ }^{6}$ The argument that the consumption tax is to be preferred as a matter of fairness has generally involved a comparison of the core ideas of the two taxes-income and consumption. Wealth-the third traditional candidate for taxation on the basis of economic resourceshas typically been left out of the comparison on the ground that whatever considerations would support wealth taxation can best be taken into account by enacting a tax on wealth or transfers of wealth, and that those quite distinct considerations should not obscure the direct comparison of the income and consumption taxes on equity grounds. This Article examines the case for consumption-tax superiority in those terms. In keeping with the focus on the core ideas of income and consumption, practical compromises that are necessary to the implementation of the taxes and that can certainly raise questions of fairness are generally not discussed. Rather, this Article is meant to be directly responsive to arguments that the income tax is unfair in basic concept, quite apart from the difficulties that might arise in implementing that concept. $^{7}$

Fairness in this context must mean, or at least involve, distributional equity-the question of how economic resources ought to be distributed in a fair society. But examining primarily that question would mean losing our subject to broader issues of political theory, such as the nature of entitlements and the appropriate relationship between the individual and the state. The subject of this Article, the core ideas of the two taxes, lies between the broader inquiry of political theory and the more particular delineation of compromises necessary for the implementation of either tax.

The income tax is undoubtedly familiar to the reader, but current consumption-tax proposals may not be. Although the case for income taxation has historically been linked with progression, while that for consumption taxation has not, the consumption tax proposed today is a personal levy that would be subject to graduated rates. In general, the goal of reaching personal consumption would be accomplished by taxing all expenditures on a cash-flow basis: all receipts, including borrowings, would be included in the tax base and all nonconsumption expenditures, including principal and interest payments on debts owed, would be deducted. Thus all savings would be treated as are certain retirement savings under present law: investments would be currently

6. See What Should Be Taxed-Income or Expenditure? (J. Pechman ed. 1980) (proceedings of conference) [hereinafter cited as BRoOKINGs REPORT].

7. The relative superiority of consumption and income taxes in terms of administrative simplicity and economic efficiency are, accordingly, not discussed in this Article. 
excluded or deducted, no tax would be imposed while the invested capital produced income so long as that income was not withdrawn for consumption, and all proceeds, whether capital or income, would be fully taxed when withdrawn for consumption. ${ }^{8}$

The result of such a cash-flow or expenditure tax, as it is called, is that only consumption would be taxed, but at rates that could be graduated on the basis of personal consumption. Personal progression is a crucial aspect of the case for such an expenditure tax, since a flatrate tax on consumption could be more easily levied as a tax on value added, which would not involve the administrative burden of personal returns. ${ }^{9}$ In accordance with current usage, the term "consumption tax" will be used here to indicate the cash-flow or expenditure tax as well as other arguably equivalent methods of reaching personal consumption.

The Article is divided into three parts. The first part elucidates the sometimes confused concept of income for tax purposes and identifies premises that would support that concept as a criterion of distributive fairness. The second part evaluates the arguments that have been advanced in favor of the consumption criterion as superior to the income criterion. It is concluded that while either tax can be justified as a means of implementing a plausible principle of distributional equity, the case for the superior fairness of the consumption tax is not persuasive on its own terms. A final part reasserts the relevance of wealth to the choice between the taxes on the grounds of fairness.

\section{Income as a Criterion of Distributive Fairness}

\section{A. The Concept of Income for Tax Purposes}

Although the theoretical tax literature is littered with multitudinous definitions of income, ${ }^{10}$ Henry Simons's famous formulation has dominated policy analysis for more than forty years:

Personal income may be defined as the algebraic sum of (1) the market value of rights exercised in consumption and (2) the change in the value of the store of property rights between the beginning and end of the period in question. In other words, it is merely the

8. See I.R.C. $\$ \$ 402-403,408-409$ (treatment of retirement savings).

9. The value-added tax has itself appeared in recent political discussions of tax policy options. See The Tax Restructuring Act of 1979, Hearings Before the Hottse Committee on Ways and Means, 95th Cong. Ist Sess. (1979).

10. See generally H. Simons, Personal Income Taxation 59-102 (1938); Wueller, Concepts of Taxable Income (pts. 1-3), 53 Polirical ScI. Q. 83, 557 (1938); 54 Political Sci. Q. 555 (1939). 
result obtained by adding consumption during the period to "wealth" at the end of the period and then subtracting "wealth" at the beginning. The sine qua non of income is gain, as our courts have recognized in their more lucid moments-and gain to someone during a specified time interval. Moreover, this gain may be measured and defined most easily by positing a dual objective or purpose, consumption and accumulation, each of which may be estimated in a common unit by appeal to market prices. ${ }^{11}$

The obvious difference between this tax base and that specified by the expenditure tax is that only consumption remains in the latter, after accumulation has been removed.12

As used in this Article, "consumption" means the ultimate use or destruction of economic resources (as by the drinking of a glass of wine) and "accumulation," the retention or saving of such resources. "Economic resources" is not a self-defining term, for its scope depends on what is considered economic activity. It will be used here to mean goods and services, whether real or financial, that are generally the subject of market transactions in our society. This category can be defined in part in principle (excluding the pleasures of one's own psyche) and in part by custom (excluding the exchange of services typical of personal relationships). However far the penumbra of economic activity might be extended, it is the core that gives central meaning to the familiar measures of economic well-being-consumption, income, and wealth-that compete for use as tax bases. That familiar core will be our subject unless a particular argument directs attention elsewhere.

Simons's idea, which is usually referred to as the Haig-Simons or accretion concept of income, ${ }^{13}$ is strictly personal in its application. As Simons himself put it, the concept is simply an arithmetical operation, designed to identify the change in a person's position over the course of an accounting period. ${ }^{14}$ It does not provide a standard for deciding

11. H. Simons, supra note 10 , at 50 .

12. Personal consumption may, of course, exceed personal income in any given year through disaccumulation or borrowing, with the reconciliation accomplished by the algebraic summing of consumption and accumulation.

13. Professor Haig earlier introduced the accretion concept: "Income is the money" value of the net accretion to one's economic power between two points of time." Haig, The Concept of Income-Economic and Legal Aspects, in The Federal Income Tax 1, 7 (R. Haig ed. 1921), reprinted in Readings in the Economics of TAXation 54, 75 (R. Musgrave \& C. Shoup eds. 1959) (emphasis omitted). Both were apparently anticipated by Georg Schanz in Schanz, Der Einkommensbegriff und die Einkommensteurgesetze, 13 Finanz Archiv 1 (1896) (introducing accretion concept). See Musgrave, In Defense of an Income Concept, 81 HaRv. L. Rev. 44, 47 n.7 (1967) (observing that Schanz was the first to propose the accretion concept).

14. H. SimoNs, supra note 10 , at 51,78 .

\section{4}


whether a given receipt, transaction, event, or whatever is income in some abstract sense. Nor does the idea usefully illuminate the nature of the aggregate tax base, let alone the appropriate taxable unit or period, a limitation not always appreciated by either Simons's disciples $^{15}$ or the denigrators of his formulation. ${ }^{16}$

What then is the importance of the Haig-Simons definition? The view taken here is that the concept is an essential but incomplete perspective on the nature of the income tax base. Specifically, the concept permits the interpersonal allocation or attribution of income to individuals, an attribution that is necessary if the tax cannot be collected at the source or if progressive rates are to be applied on a personal basis. Consider an agrarian society in which all citizens toil with their own nondepreciating tools in a collective corn field, with the crop the only income produced by the economy during the year. No matter how the citizens divide the crop among themselves, the government can collect a ten percent income tax without the HaigSimons definition; it need only take ten percent of the crop from the field, with the farmers dividing the rest in accordance with their claims, which we shall assume are based on the combined productivity of their labor and tools. Only if a personally progressive-or regressive-tax is levied, or if there is no convenient way of reaching the income at the source, or both, would it be necessary to determine how much of the society's income ended up in the hands of each individual. That is precisely the determination made by the Haig-Simons definition.

If the Haig-Simons formulation were not available, what would have permitted our hypothetical government to conclude that its ten percent tax was levied on income? Probably the most familiar and intuitive definition of income is that of product. As the Supreme Court once put it: "Income may be defined as the gain derived from capital, from labor, or from both combined."17 This idea, which was espoused by early advocates of the income tax, ${ }^{18}$ but which has been much denigrated by later theorists and abandoned by the Supreme Court, ${ }^{19}$

15. See Musgrave, supra note 13, at 53-62, reprinted in B. BittKer, C. Galvin, R. Musgrave, \& J. Pechman, A Comprehensive Income Tax Base? A Debate 62, 72-80 (1968) [hereinafter cited as CTB DEBATE]; Musgrave, Rejoinder, in id., at 114.

16. See Bittker, $A$ "Comprehensive Tax Base" as a Goal of Income Tax Reform, 80 HaRv. L. Rev. 925 (1967), reprinted in CTB DEBATE, supra note 15, at 1; Bittker, Comprehensive Income Taxation: A Response, 81 HARv. L. REv. 1032 (1968), reprinted in CTB DeBate, supra note 15, at 102; Bittker, $A$ Last Word, id. at 125.

17. Eisner v. Macomber, 252 U.S. 189, 207 (1920).

18. See, e.g., E. Seligman, The Income Tax 12-15 1911); $c f$. A. Smith, The Wealth of Nations bk. II, ch. ii, at 271 (Modern Library ed. 1937) (defining income in similar manner).

19. Commissioner v. Glenshaw Glass Co., 348 U.S. 426, 430-31 1955). 
derives from the fundamental observation that labor as well as capital is productive, with the output of that productive activity constituting the tax base. Our agrarian tax plainly meets this definition of an income tax. Moreover, it is neither a consumption tax (the corn might not all be consumed), nor a wealth tax (some workers may have stores of corn from prior periods), nor a wage tax (it reduced the return to capital, i.e., tools, as well as labor). It is, rather, a tax levied on social output or production for the period.

Unlike the Haig-Simons concept, the product formulation identifies a concept of the aggregate tax base: the product of the whole society's private capital and labor during the accounting period. ${ }^{20}$ The product formulation can also be used to answer the question of whether a particular item constitutes income in some abstract sense; wages, for instance, do, while totally unexpected returns-windfalls-do not, if unrelated to an individual's labor or capital. Those two answers also illustrate the defect of the product view by itself, and the corresponding virtue of the Haig-Simons concept: arguably equivalent changes in personal economic position are treated differently depending on the origin of the change.

The Haig-Simons concept is necessary to identify personal income when a society wishes to implement a tax with personally graduated rates or is too complex to permit collection at the source. The arithmetical process of the Haig-Simons definition should not, however, obscure the nature of the aggregate tax base, which is the product of the society's private capital and labor for the accounting period. The HaigSimons calculation simply identifies how much of that product has ended up in each taxable unit. What is involved here is not merely a quibble about whether an idealized "definition" of income for personal taxation should focus on the required interpersonal accounting or on the product that is accounted for. Rather, both perspectives are necessary to answer properly questions about income measurement in a complex society, with neither concept having primacy over the other. ${ }^{21}$

It is, of course, standard fare of tax analysis since at least Henry Simons that personal income does not sum to the total private social product of the accounting period. ${ }^{22}$ Putting aside what is not central

20. The return on public capital, such as parks or dams, generally has not been included in specifications of the income tax base. Cf. Aaron, What is a Comprehensive Tax Base Anyway? 22 NAT'c TAx J. 543 (1969) (arguing that public goods and services would be included in an ideal tax base).

21. The equivalence of national product with income to a nation's factors of production is a familiar accounting identity in national income accounting. See R. STONE \& G. Stone, National Income and Expenditure 31-32 (10th ed. 1977).

22. See, e.g., H. SimoNs, supra note 10 , at 47 . 
for our purposes-institutional differences in the current measurement of individual and social income, as well as any conceptual problems in comparing aggregations of market prices $^{23}-$ it is difficult to see why Haig-Simons personal income would not aggregate to the total product of a society's privately owned capital and labor. To the extent that Haig-Simons income includes the product of all individuals' capital and labor, the sum of the individual amounts could differ from the social product only by the amount of transfers among individuals. Yet the Haig-Simons calculation takes all such transfers into account by offsetting entries, so the total should remain unchanged. A few examples will make this clear.

Suppose that a citizen of our agrarian society finds 100 ears of corn, which he is permitted to keep under local law. Although his HaigSimons income has increased, while the society's. product has not, the equivalence is maintained by the diminution in the Haig-Simons income of the loser of the corn. To be sure, the equivalence would not hold if the corn were literally manna from Heaven, but the incomeas-product view admits of no free lunch (corn or otherwise), a view that seems perfectly sensible to me, since (alas) true manna has not been observed in recent times.

Now suppose that our citizen owns a certain amount of beach land, which vacationers have generally regarded as equal in desirability to a comparable amount of mountain land. If for some unanticipated reason the tastes of vacationers shift significantly in favor of the shore over the stream, our citizen will be the beneficiary of another gain. Once again, he would have Haig-Simons income-his land would trade for many more bushels of corn than it did before-while there would have been no addition to the society's product. Yet the equivalence holds because there would be a decline in the relative value of some assets other than the beach land, presumably including the mountain land.

To return to our own economic system, a capital gain due to a change in stock-market prices may likewise add nothing to the social product and yet provide Haig-Simons income to the recipient. Again, there would presumably be offsetting losses elsewhere in the economy, perhaps in the stock market, so that there is no incongruity in taxing capital gains (and permitting a deduction for capital losses) under an income tax where aggregate income is defined as the product of capital and labor.

23. Nor need we be concerned with such matters as whether national income is best expressed before or after taking into account depreciation of the capital stock and indirect taxes. See pp. 1117-20 infra. 
Consider another category of transfers: gifts and bequests. Gratuitous receipts do, after all, increase either the consumption or wealth of the donee and should be counted as part of his Haig-Simons income. On the other hand, such receipts do not constitute an additional product of capital or labor, so they cannot be counted again if the donor has already included them as part of his income. Thus the equivalence holds only if the donor is permitted a deduction for the gift because his net worth has declined, a result which seems obvious under the Simons definition quoted above. As under current law, one might, of course, decide to tax the amount of the gift to the donor if the opportunities to shift tax liabilities by gift were thought too great under graduated rates. ${ }^{24}$ And even if taxation to the donor rather than the donee were rejected for inter vivos transfers, it might be preferable with respect to bequests. What is not permissible under the Haig-Simons concept is inclusion of the receipt in both the donor's and the donee's incomethe position erroneously taken by Henry Simons ${ }^{25}$ and many other writers. ${ }^{26}$ That position can be sustained only on a view of income quite different from the Haig-Simons concept, a matter to which we will return. ${ }^{27}$

The equivalence of aggregate Haig-Simons personal income and social product also holds in the case of technological advances that increase the society's production possibilities. Suppose in our agrarian society that a machine is invented that doubles the potential output of the field. If the machine is regarded as an output in the year of its production, social product is augmented by the same amount as the inventor's net worth. If a natural resource that, when used as a fuel, will double the output of the machine is then discovered under a citizen's privately owned home, inclusion of the resource in social production as a return to the homeowner's capital will accomplish the same result.

A final aspect of the equivalence between social product and total personal income is that there could be Haig-Simons income even in a society that had no social product. Survivors of a shipwreck who were marooned on a desert island, and who spent their time gambling their shares of the ship's food stores that washed ashore with them, would

24. Current law excludes gifts from the income tax base of the donee, see I.R.C. $\$ 102$, and effectively includes gifts in the income tax base of the donor by denying a deduction. The potential for such shifting can be thought of as a consequence of incorrectly defining the taxable unit as individuals or married couples, as opposed to the family.

25. H. Simons, supra note 10 , at 134-40.

26. See, e.g., BlueprinTs, supra note 3, at 36-38.

27. See pp. 1095.97 infra. 
experience gains and losses among themselves as a result of the gambles, so some individuals might have positive income in the Haig-Simons sense. $^{28}$ There would not, of course, be any personal income in the aggregate since the gains would just offset the losses. Nor would there be any social product since neither capital nor labor would be employed in this society.

The equivalence argued for here does not seem confirmed in common experience in some instances because assets such as land and corporate securities appear to increase or decrease in value without any corresponding offset elsewhere in the economy. It is submitted that the equivalence exists, but is obscured by the complexities of our economy, especially when the general price level is not fixed. Imagine a simpler society in which there are only two assets of equal value-a parcel of land and a piece of machinery. If the land tripled in value relative to the machine, there would be no doubt that the landowner was better off relative to the machine owner (the machine could now be obtained in exchange for only a third of the land). Correspondingly, the machine owner would be worse off relative to the landowner (since the machine would now bring only a third of the land in exchange). The nature of relative prices is such that the landowner's gain is simply a different way of expressing the machine owner's loss.

Now consider the same transaction in a monetary economy in which the two assets are initially each valued at $\$ 100$. It is conceivable that the land could increase in value to $\$ 300$ without a corresponding decline in the dollar value of the machine if the society's monetary policy so permitted. Prior to the shift, the landowner and the machine owner each held one-half of the value of the society's real wealth. The shift increased the landowner's portion to $3 / 4$ and diminished the machine owner's to $1 / 4$, a gain of $1 / 4$ to the former and a loss of $1 / 4$ to the latter, even though there was no decline in the absolute dollar value of the machine. Whether that change in position should be reflected by a deductible loss of $\$ 100$ to the machine owner and a $\$ 100$ gain to the landowner instead of simply a $\$ 200$ gain to the landowner depends on the proper accounting for changes in the monetary unit. ${ }^{29}$ Whether

28. The example assumes that the gambles are entered into for profit and that there is no significant consumption in the act of gambling itself. One justification for the limitation on the deductibility of gambling losses under current law, see I.R.C. $\$ 165$ (d) (gambling losses deductible only to extent of gambling gains), might be the presence of a significant consumption component in the gambling itself.

29. If the increase in the total value of both assets from $\$ 200$ to $\$ 400$ were considered general price inflation, it would be necessary under an income tax triggered by realization events to increase the basis of each asset by the rate of inflation (in the instant case, $100 \%$ ) in order to compute income properly. Assuming the assets had been purchased 
current law makes the correct accounting entries or not, the landowner's gain is matched by the machine owner's loss.

To recapitulate, it is the product of private capital and labor that provides the sum of taxable income for the period, and it is the HaigSimons formulation that properly identifies that income with persons. ${ }^{30}$ The first concept is inadequate without the second in a complex economy with progressive taxation; the second is a personal calculation that has no aggregate significance without the first.

\section{B. Why Tax Income?}

Using the Haig-Simons concept of income in order to compute each taxpayer's share of the annual social product, an income tax serves to deflect to the government a progressive portion of each citizen's share of the product otherwise allocated to him by transfers and the marketplace. Whether the tax proceeds are used for public goods and services or for redistribution to some persons, either in cash or in kind, those uses are funded by the output of labor and private capital during the current period. Levying the tax on income is on this view simply a logical concomitant of the proposition that society in general has a claim on its annual product that is prior to the claims of its individual citizens.

The existence of a collective claim on privately produced resources is so well-established as part of our polity that justification may seem superfluous. Nevertheless, economic theorists have formally shown that certain goods and services are best produced in the public sector, ${ }^{31}$

prior to the shift in market value for $\$ 100$ each, the following gains and losses would result from sale after the shift:

$\begin{array}{lcc} & \text { Landowner } & \text { Machine owner } \\ \text { Amount realized } & \$ 300 & \$ 100 \\ \text { Adjusted basis } & -200 & -200 \\ \text { Gain (loss) } & 100 & (100)\end{array}$

For general discussions of the effects of inflation on income taxation, see INFLATION AND THE Income $\operatorname{TAX}$ (H. Aaron ed. 1976).

30. Viewing the Haig-Simons definition in this manner does not undermine the importance of its proper explication. Whether, for example, charitable contributions should be deductible can be thought of as raising the question of whose tax base-the donor's or the donee's-should include the consumption or accumulation that results from the transfer. Cf. Andrews, Personal Deductions in an Ideal Income Tax, 86 Hafv. L. Rev. 309, 344-75 (1972) (using Haig-Simons definition to determine propriety of charitable contribution deduction).

31. See, e.g., SamueIson, The Pure Theory of Public Expenditure, 36 REv. Econ. \& Sratistics 387, 387-89 (1954); Samuelson, Diagrammatic Exposition of a Theory of Public Expenditure, 37 Rev. Econ. \& STatistics 350 (1955). 
while political theorists have argued for centuries over the nature and extent of the collective claim for redistributive purposes, a subject that has commanded renewed attention in recent years. ${ }^{32}$ But neither the theories of public goods nor those of distributive justice have depended on the source of revenues used for the two analytically distinct governmental purposes. Discussions of redistribution generally either have considered the appropriate distribution of economic resources without identifying the best measure of such resources or have assumed that it is income (as product) that is or is not subject to a collective claim. As a result, existing theories of distributive justice and public goods have little to add to the case for the income tax beyond establishing a social claim on private resources.

Specifying that claim as on social product can be justified on the theory that a producer does not have a controlling moral claim over the product of his capital and labor, given the role of fortuity in income distribution and the dependence of producers on consumers and other producers to create value in our society-factors that create a general moral claim on all private product on behalf of the entire society. ${ }^{33}$ This rationale would apply a fortiori to other increments in HaigSimons income, such as gifts and windfalls, which come to the recipient without even the claim due to production. Such a proposition is, of course, no more demonstrable than the proposition that society has a prior moral claim on wealth or consumption rather than on product. As Professor William Andrews has stated, the ultimate choice among these alternatives is not a matter of logical proof but of exposing the assumptions and identifying the consequences of each. ${ }^{34}$

Given that limitation, the case for taxing income can be stated by identifying as a plausible assumption the view that, for the reasons suggested above, the distribution of social product is a matter for collective decision. The collective decisionmaking apparatus of the society is conceived of as deciding both the amount and type of public goods to be produced and the distribution of that portion of private social product that remains after diversion of resources into the public sector to produce those public goods that are not financed by service charges. Whatever after-tax distribution is decided upon, that decision

32. The seminal work in rekindling interest in distributive justice is J. RAwLS, A THEORY OF JUSTICE (1971).

33. See id. at 72-74, 100-08, 310-15. For a recent argument that treatment of an individual's genetic endowment as an accident devoid of moral significance is inconsistent with basic concepts of individuality, see Posner, Utilitarianism, Economics, and Legal Theory, 8 J. LeGal Stud. 103, 128 (1979).

34. Andrews' Reply, supra note 1 , at 950. 
is implemented by the income tax, which is levied on the amount of social product otherwise distributed to each taxable unit.35

As anticipated, this argument for the income tax does not appeal to some independently demonstrable principle but is tautological in the sense that it follows simply from the premise of the tax: given a legitimate social concern with the distribution of society's product, the income tax is justified as a means of effecting the desired after-tax distribution. The nature of the desired distribution goes to the content of the tax, rather than to its justification. Extreme egalitarianism would presumably argue for a tax characterized by progressivity, culminating in a confiscatory rate on positive income with corresponding provisions specifying a minimum after-tax income. A social decision to reduce inequality in the distribution of product, but not to the extent of eliminating incentives to work and invest, might lead to less progressivity with rates always under one hundred percent. It is a judgment of this latter type that seems to underlie much current discussion of distributive justice. ${ }^{36}$

Unlike the foregoing argument, the traditional case for the income tax in terms of fairness has appealed to some external standard to establish that income is an appropriate basis for taxation. Generally it has been argued that income is a superior index of an "ability to pay," and that the tax should be structured to result in "equal sacrifice" by taxpayers, the latter being especially relevant to the rate structure. Unfortunately, centuries of elucidation have failed to provide sufficient content to these concepts. For example, ability to pay has been defined as "the capacity of paying without undue hardship on the part of the person paying or an unacceptable degree of interference with objectives that are considered socially important by other members of the community." 37 Such definitions reduce to statements that society should appropriately tax what it should appropriately tax. This approach is no less tautological than the one taken here; it just appears so in that

35. This view includes the possibility of negative taxes and assumes that the desired after-tax distribution of income is a function of no personal characteristic other than pretax income. For example, if after-tax income were to be allocated on the basis of weight, intelligence, merit, or whatever, the Haig-Simons definition could be used for collection of revenue, but not for the simultaneous achievement of a given after-tax distribution.

36. See, e.g., A. Okun, Equality and Efficiency-The Big Tradeoff (1975); J. Rawls, supra note 32 , at $150-61$.

37. R. Goode, The Individual Income TAx 18 (1964); see Gunn, The Case for an Income Tax, 46 U. CHI. L. REV. 370, 378-88 (1979). The theory of marginal sacrifice is discussed in W. Blum \& H. Kalven, The Uneasy Case for Progressive Taxation 39-70 (1953). 
apparently, but not really, independently verifiable grounds, such as ability to pay, are said to justify the tax.

To summarize, the personal income tax follows from, and is justified by, a societal judgment as to the appropriate distribution of social product or personal income. Society's interest in the distribution of income, in turn, depends on the view that the importance of fortuity and the interrelationships of contemporary society deprive producers of a controlling moral claim to what would be distributed to them in the absence of a tax system.

\section{Consumption as a Criterion of Distributive Fairness}

\section{A. Why Tax Consumption?}

It will be recalled that the consumption tax being proposed currently is a personal tax with graduated rates, falling on the consumption, but not the accumulation, branch of Haig-Simons income. In general, the tax would be administered on an expenditure or cash-flow basis: all receipts, including borrowings, would be included in the tax base and all nonconsumption expenditures, including principal and interest repayments, would be deducted.

The case for the resulting tax base as a matter of distributive fairness is that society's interest in a just distribution of economic resources goes to standards of living rather than to social product. ${ }^{38}$ Under this view, the collective decisionmaking apparatus is conceived of as deciding both the amount and type of public goods to be made available for public consumption and the appropriate after-tax distribution of private consumption, which is effected by the consumption tax.

Specifying the social claim on private resources as a claim on consumed resources rather than on social product, as under an income tax, is justified on the view that the ultimate goal of productive activity is human consumption, so that unconsumed product is simply not relevant to a distributional calculus. In effect, unconsumed product is ignored until actually consumed, at which time it is subject to the social claim.

Under a consumption tax, a citizen's moral claim is for a fair sharehowever computed-of the goods and services consumed during the accounting period. Under an income tax, it is for a fair share of the goods and services produced during the period. An extreme egalitarian would seek equality among consumers (and nonconsumers) under the

38. See Consumption Tax, supra note 1 , at 1167 . 
first, and equality among producers (and nonproducers) under the second. Either criterion of distributional equity seems plausible as an initial matter.

\section{B. Arguments that the Consumption Tax is Preferable as a Matter of Fairness}

Consumption tax advocates have advanced six grounds for regarding the income tax as inferior in terms of fairness: (l) the income tax unfairly takes into account resources left in the common pool; (2) consumption more closely approximates utility, the ideal measure of distributional justice; (3) income taxation discriminates against savers; (4) consumption taxation is preferable from a lifetime perspective; (5) the concept of income is inherently defective; and (6) consumption taxation would interfere less with individual liberty.

Each of these arguments, recited above in the rough order of their historical appearance, will be considered separately.

\section{The Common Pool}

From the perspective of the income tax, the consumption tax is deficient because it fails to take into account the fact that productive nonconsumers receive claims for future consumption in the form of property rights. Such producers have not only current consumption, but also an option for additional consumption that can be exercised at will. Why, from the point of view of distributional fairness, should the existence of such options be ignored?

The traditional answer, which derives from Hobbes, is that unconsumed resources are left in a common pool, so that it is inappropriate to tax a person until he withdraws his resources for personal consumption. ${ }^{39}$ Indeed, leaving resources in the common pool can be characterized as socially desirable in that the capital so supplied will increase both future production and the future productivity of workers. ${ }^{40}$

The image of a common pool certainly fails to capture the reality of existing legal relationships in our society if it is meant to suggest that all members of the society have equal access to the pool, which is, after

39. T. HobBes, supra note 5 , at 226 , makes the argument in the form of a question: For what reason is there, that he which laboureth much, and sparing the fruits of his labour, consumeth little, should be more charged, then he that living idly, getteth little, and spendeth all he gets; seeing the one has no more protection from the commonwealth, than the other?

The "common pool" language is used by other commentators. See C. Fried, RIGHT AND Wrong 147 (1978); N. KALDOR, supra note 5, at 53. The Hobbesian formulation is rejected in Warren, supra note 1 , at 933.

40. See N. Kaldor, supta note 5, at 53; P. MIEszKowsKr, supra note 3, at 8.9; R. Musgrave \& P. Musgrave, Public finance in Theory and Practice 220-21 (2d ed. 1976). 
all, merely the aggregate of society's current private wealth. That pool is not collectively owned, but held privately by shareholders whose shares are simply their claims on unconsumed product. The commonality of the common pool has only to do with the derivative benefit to society of saving and investment, not in any generality of ownership or control; nor is the aura of moral superiority that sometimes surrounds those who leave their goods in the pool justified. Accumulation of wealth in our society is not a matter of altruistically forgoing current consumption for the good of others. Rather, it is a matter of a saver choosing to defer until a later date either his own consumption or that of an object of his bounty.

As powerful an image as it is, the idea of a common pool simply does not add anything to the straightforward proposition that distributive justice should turn on standards of living. Like the Haig-Simons concept, the common pool idea can be cast in accounting terms: if product is not currently consumed, what happens to it? By definition, it remains in the pool of the productive resources, contributing to additional product and awaiting conversion into future consumption. The idea of such a pool may confirm the plausibility of consumption as a criterion of distributive justice, but it hardly shows the superiority of that criterion over the concept of income.

\section{Consumption Taxation and Utility}

It might be argued that distributive justice should be concerned not merely with income or other measures of economic well-being, but with all sources of an individual's utility, satisfaction, or welfare. Under this view, an ideal tax would be one that implemented society's view of the appropriate distribution of utility (to use the term still favored by economists) by taking into account not only income, but all other sources of satisfaction as well.11 Although not perfect, a consumption tax would be the closest possible approximation to this ideal, because consumption is the closest observable phenomenon to utility.

This view focuses not on the individual's share of the social product, but rather on what he does with it: ultimately, product is desired, and presumably used, for the provision of satisfaction or utility:

[F]undamentally income is a flow of satisfactions, of intangible psychological experiences. If one receives a dollar he receives something which he ordinarily can and does spend-perhaps for a dinner. Is his income the dollar, or is it the dinner which he buys

41. See Rosen, An Approach to the Study of Income, Utility and Horizontal Equity, 92 Q.J. EcoN. 307 (1978) (using utility definition of horizontal equity to evaluate an existing tax structure). 
with the dollar, or is it, at bottom, the satisfaction of his wants which he derives from eating the dinner-the comfort and the sustenance it yields to him? If one spends his dollar for something more durable than a dinner-say a book or a pipe-is his true income the book or the pipe, or the series of satisfactions or "usances" arising from reading the book or smoking the pipe? There is no doubt as to the answer to these questions. A man strives for the satisfaction of his wants and desires and not for objects for their own sake. ${ }^{42}$

The argument that distributive justice would ideally comprehend all forms of utility should be rejected as a foundation for consumption taxation for three reasons. First, if consumption-or income-is ultimately a mental or psychological concept, the tax base no longer follows precisely from observable transactions. Rather, an accurate determination of tax liability on this theory would require knowledge of each person's capacity for pleasure, because identical objects purchased for identical prices would almost surely give rise to different amounts of psychic income in different psyches. There apparently could also be a kind of manna under this view, in that a pleasurable sensation arising without an increase in social product would presumably be income. The psychological nature of this concept plainly makes it unworkable as a touchstone for taxation, because it requires calculation of amounts that are totally unknowable. As stated at the outset, this Article generally avoids discussions of relative administrative practicality. But the impossibility of developing a workable consumption tax, founded on interpersonal utility comparisons that simply cannot be made, is a difficulty of a different order.

Second, even if the measurements were technically feasible and the underlying ideas could be made sufficiently intelligible, expansion of the concept of distributive justice in this manner would not be desirable as a matter of policy. Our society has never viewed taxation as a means of reducing all differences among individuals. The respect accorded noneconomic differences by our political system is based on

42. Haig, supra note 13 , at 2. The language quoted in the text makes somewhat problematical Haig's connection with what is usually called the Haig-Simons concept. $B u t$ see note 13 supra.

The most influential exponent of income as satisfaction was Irving Fisher, who thought the most fundamental concept of income was enjoyment or psychic income, consisting of agreeable sensations and experiences. See I. Fisher, The Nature of Capital and Income 165-79 (1906). The goods or services that produced the satisfactions were important only as an approximation of the psychic flows, and the costs of those goods and services represented only a means of aggregating the approximate value of heterogeneous goods and services. Although he insisted on calling it an income tax, Fisher concluded that the closest achievable approximation of a tax on psychic flows was what today would be called a personal consumption tax. 
more than the practical difficulties of moving beyond economic characteristics; arguably it derives from fundamental views about the primacy of persons over things, views that assume it is possible to treat people as distinct from their product, whether consumed or not, ${ }^{43}$ a distinction that would not obtain under the broader utilitarian view of distributive justice.

Third, even if utilitarianism were accepted as an appropriate criterion for choosing among tax bases, it is not obvious that the best approximation of utility in terms of economic resources would be consumption alone. Individuals are certainly not indifferent to the holding of wealth, and it seems unlikely that the satisfaction derived from being wealthy is limited to any future consumption to be purchased with the wealth. Thus, wealth might be a suitable partial proxy for utility, and, in the absence of a wealth tax, so might income, which includes accumulation as well as consumption.

Thus the utilitarian formulation of distributive justice, along with the derivative concepts of consumption and income as psychic benefits, should be rejected even if workable, on the ground that psychological well-being is not an appropriate measure of distributive justice given our moral and political traditions. ${ }^{4}$ Tax bases and the underlying concepts of distributive fairness should be limited to economic resources, and the choice among such bases is not made easier by taking consumption as a surrogate for utility.

\section{Discrimination Against Savers}

To demonstrate the unfairness of the income tax, Irving Fisher offered the example of three brothers who each inherit $\$ 10,000$ in a taxfree world where the interest rate is five percent. ${ }^{45}$ The first brother invests his inheritance in a perpetual annuity of $\$ 500$ a year; the second puts his in a trust with income to accumulate for fourteen years, at which point the corpus will be worth $\$ 20,000$ and will be used to purchase a perpetual annuity of $\$ 1,000$ a year; the third purchases an annuity of $\$ 2,000$ a year for about six years. In a world without taxation, the present value of each brother's asset is, at five percent, $\$ 10,000$. The

43. But see R. Nozick, ANARchy, State, ANd Utopia $169-72$ (1974) (equating taxation of income from labor or capital with forced labor and arguing that such taxation gives the state a property right in the individual); Posner, supra note 33 , at 128 ("To treat the inventor and the idiot equally so far as their moral claim to command over valuable resources is concerned does not take the differences between persons seriously.") (footnote omitted).

44. An argument for the consumption tax on the basis of utilitarianism in the context of a life-cycle model is discussed in note 67 infra.

45. See I. FisHER, supra note 42, at 249.53. 
present value of each brother's future tax liability would not, however, be the same under an income tax. If the tax rate were ten percent, those amounts would be, respectively, $\$ 1,000, \$ 1,714$, and $\$ 157.73 .^{40}$ Deferral of consumption results in additional interest and additional income taxes, from which Fisher concluded: "Such a system of taxation is clearly unjust and discourages the saver, while it encourages the spendthrift." 47

One wonders not only why the tax is clearly unjust, but why the comparison is even relevant. Fisher's conclusion turns on the assumption that fairness is to be measured in terms of taxpayers' expectations (here expressed as a present capital value of $\$ 10,000)$, rather than outcomes. Fisherian capital theory takes expected income streams in future periods as given and discounts them to a current capital value that embodies the world's expectations about the asset's future. The HaigSimons calculation, by contrast, takes market-determined capital values as given and identifies changes in their amounts to arrive at income for a past period. The Haig-Simons concept is retrospective, concerned with the change in each taxpayer's position during the period just ended, while the Fisherian analysis is essentially prospective: the brothers are said to be in the same position because they have the same prospect. Both views depend on capital values and so involve the market's evaluation of future income streams. The difference lies in the perspective from which interpersonal comparisons are made-the Fisherian comparison is forward-looking, while the Haig-Simons concept (and the standard-of-living view of the consumption tax) is backward-looking.

In a world characterized by uncertainty, expectations may not be what eventuates, so a choice must be made between comparing taxpayers on an ex ante or an ex post basis. Expectations are, of course, central to economic theory, which is in general concerned with the making of rational choices ex ante. But fairness in taxation should depend on outcomes, not expectations. If $A$ and $B$ have identical expectations about their financial futures, but A's hopes are dashed, while B's wildest dreams are realized, should not a fair tax system take into account the differences in outcome? ${ }^{\text {?8 }}$

46. Id.

47. Id. at 253 .

48. For discussion of a similar issue in the theory of social choice-whether the mathematical expectation of welfare or the actual distribution of welfare should be considered in choosing among alternative social states-see A. SEN, Collective CHOICE AND SocIAL WeLFARE 141-46 (1970); Diamond, Cardinal Welfare, Individualistic Ethics, and Interpersonal Comparison of Utility: Comment, $75 \mathrm{~J}$. PoLITICAL ECON. 765 (1967); Harsanyi, Cardinal Welfare, Individualistic Ethics and Interpersonal Comparison of Utility, 63 J. Political Econ. 309, 312-14 (1955). 
Even if investment return is certain, as it is in the example of the three brothers, the discounting of future consumption to present value or the compounding of present to future value, which is the core of the Fisherian argument, cannot be carried over from ex ante to ex post perspectives. There is, to be sure, no difference between the perspectives in the purely hypothetical world of complete certainty in which an individual can see the future as clearly as the past. But that is not our world; nor is the ability to see into the future a necessary corollary of the existence of risk-free investments on which there is a guaranteed return.

Consider two taxpayers who each earn $\$ 200$ in Year 1 , and who accordingly have the same prospect. One (A) consumes all he can after taxes in Year 1, while the other (B) defers all his consumption-at ten percent interest-from Year I to Year 2, when they both die (as expected) without earning additional labor income. As the following table indicates, the rate of exchange between consumption in Years 1 and 2 is changed by an income tax, but not by a flat-rate consumption or wage tax. ${ }^{49}$

\section{TABLE I}

\begin{tabular}{lrrrr}
\multicolumn{1}{c}{ A } & No Tax & Income Tax & Consumption Tax & Wage Tax \\
Pretax wage & $\$ 200$ & $\$ 200$ & $\$ 200$ & $\$ 200$ \\
Tax on wage (50\%) & 0 & 100 & 100 & 100 \\
After-tax consumption (Year 1) & 200 & 100 & 100 & 100 \\
\multicolumn{1}{c}{$B$} & & & & \\
Pretax wage & 200 & 200 & 200 & 200 \\
Tax on wage (50\%) & 0 & 100 & 0 & 100 \\
After-tax investment & 200 & 100 & 200 & 100 \\
$\begin{array}{l}\text { Pretax investment proceeds } \\
\text { Tax on investment proceeds (50\%) }\end{array}$ & 220 & 110 & 220 & 110 \\
After-tax consumption (Year 2) & 220 & 5 & 110 & 0 \\
Ratio of Year 2 to & & 105 & 110 & 110 \\
Year 1 consumption & $220 / 200$ & $105 / 100$ & $110 / 100$ & $110 / 100$
\end{tabular}

An income tax, unlike consumption or wage taxes of the same rate, reduces the value of future consumption relative to present consump-

49. Equivalent results under the consumption and wage taxes require the following assumptions in addition to fixed tax-rates: (1) accumulation does not continue forever, so there is never any consumption to tax; (2) cohsumption does not occur without there having been wages to tax; (3) taxpayers are rational and do not save a fixed fraction of their pretax wages; (4) wages can be distinguished from capital income; and (5) the pretax rate of return remains fixed. See $\mathbf{R}$. Musgrave, The Thzory of Public Finance 262, 266-67 (1959).

The fact that consumption and wage taxes of equal rates yield equal results is an aspect of the phenomenon that deferral of a constant-rate income tax is the equivalent of nondeferral coupled with exemption of the return on the invested proceeds of the taxed receipt. See MEADE REPort, supra note 4, at 35-38; Consumption Tax, supra note 1, at 1123-28; Brown, Business-Income Taxation and Investment Incentives, in INCOME, EMployment and Public Policy, Essays in Honor of Alvin H. Hansen 300, 309-10 (1948). 
tion (from $110 / 100$ to $105 / 100$ in the example above)-a result that led John Stuart Mill to conclude that savings are "twice taxed." ${ }^{50}$ Ex ante, the income tax arguably discriminates against $B$, because $A$ and $B$ start in the same pretax position in Year 1, but pay different taxes in terms of present value. While A's and E's consumption have the same pretax present value in Year 1, B's consumption has a lower Year 1 present value after payment of the income tax. The consumption tax can thus be said to be fairer ex ante, in that it does not discriminate against taxpayers with a relatively greater preference for future consumption.

The same argument cannot be made ex post without showing that $A$ and $B$ would be in equal positions in Year 2, but for the tax. B's consumption in Year 2 can be discounted to Year 1 to show ex ante equivalence, but can A's consumption in Year $I$ be compounded to Year 2 to show ex post equivalence? ${ }^{51}$ To do so would imply a capital return to all consumption expenditures over the remainder of the consumer's lifetime, meaning that, at any given moment, more recent consumption is worth less to consumers than an equivalent amount of earlier consumption-a result that is certainly not intuitively obvious.

Although rational consumers may discount the cost of future consumption to present value when choosing among allocations of consumption over their lifetimes ex ante, it does not necessarily follow that more recent consumption is worth less ex post. It is not at all obvious that consumption of a bottle of fine wine thirty years ago is, in any meaningful sense, equivalent to consumption of several cases today. It may well be that proximity in time is what matters, rather than priority. Because we go through time in only one direction during our lifetimes, we are never presented with an opportunity to prefer priority independently of proximity. Or it may be that a rational consumer would not discount consumption qua consumption, even $e x$ ante, in that each period in his life would be given equal weight. ${ }^{52}$ Marooned on a desert island with a lifetime store of goods, a consumer might well allocate an equivalent amount of goods to each of the remaining years of his life. From this perspective, the discount observed ex ante is due

50. J. S. MiLL, supra note 5, at 54-55.

51. See White, Proper Income Tax Treatment of Deductions for Personal Expense, 1 House Commitiee on Ways and Means, Tax Revision Compendum 365 (Comm. Print 1959) (discussing an imputed return to consumption over time).

52. Rawls argues that individuals in the original position would have no time preference. See J. RAwLs, supra note 32, at 293-98. 
entirely to the productivity of capital, which permits the augmentation of consumption through deferral and investment..$^{53}$

From either perspective, the discount observed in consumer decisions ex ante does not establish the propriety of compounding earlier consumption ex post. Yet that is the mandate of the Fisherian view, translated into ex post terms for the clearest comparison with the HaigSimons concept: interest should not be taxed to $B$ because it is not taxed to $A$, who had exactly the same amount of imputed return on his consumption. The Fisherian argument seems so strange in ex post terms precisely because, unlike the Haig-Simons concept, it is essentially an ex ante formulation. For myself, the discrimination argument is not convincing even when investment return is certain, as in the examples discussed so far. But even if the argument were accepted in those instances, its application to the more realistic case of uncertain investment return is more difficult-a matter addressed in the next section.

\section{The Consumption Tax From a Lifetime Perspective}

The Fisherian analysis has reappeared in recent years in arguments against the income tax based on life-cycle consumption models. The United States Treasury Department has presented the lifetime-consumption argument as a matter of "endowment": if the expected wagestream for each individual is discounted to a comparable present value, and added to the value of property held at that point, then the sum represents an endowment that can be regarded as a good measure of ability to pay taxes..$^{54}$ Once endowment is accepted as the appropriate means of ranking taxpayers in terms of ability to pay, it follows that an income tax is inferior to a consumption or wage tax, since an income tax will tax equally endowed taxpayers differently, if their spending patterns differ. The Treasury Department concluded that a consumption tax is an "ideal [lifetime] wealth tax," as equivalent to a flat-rate tax levied on endowment. 55

When investment return is certain, the endowment rationale is sim-

53. If the interest rate is thought to be determined ultimately by government policy, the reduction of the after-tax rate (from $10 \%$ to $5 \%$ in Table I) under the income tax suggests that the pretax interest rate might be commensurately raised to $20 \%$ if an income tax is imposed. Given such an increase, there would be no difference in result under the income and consumption taxes when rates and returns were certain, so neither tax could be said to be superior.

54. For taxpayers who leave no bequests and make no gifts, this endowment is also the present value of their expected lifetime consumption.

55. Blueprints, supra note 3, at 42; see Musgrave, ET, OT and SBT, 6 J. PuB. Econ. 3, 11-12 (1976) (describing endowment rationale in terms of equal options). 
ply the Fisherian analysis extended over a taxpayer's lifetime. The Treasury's analysis made explicit the wage tax equivalence shown in Table I by permitting taxpayers to choose between the standard consumption tax treatment of deducting investments and including disinvestments (what is called the "qualified account" alternative) and simply excluding capital income from the tax base, which becomes to that extent a wage tax base (the "prepayment" alternative). ${ }^{.56}$

\section{a. Risky Investments}

Assume that the two wage earners described above-each of whom earned $\$ 200$ in Year 1-can invest and borrow at a riskless interest rate of ten percent and that there also exists a risky investment, such as a coin toss, that offers an investor the opportunity to triple his initial investment or lose it all after one year. Our two investors can vary the risk in their portfolios by varying the amount allocated to risky and riskless assets and by borrowing if they wish. In the interest of simplicity, imagine that each invests his entire after-tax wages of $\$ 100$ in the risky asset under an income tax, so that each has a fifty percent chance of receiving $\$ 300$ and a fifty percent chance of receiving zero in Year 2 before taxes. ${ }^{57}$ The expected after-tax results are as follows:

\begin{tabular}{lcc} 
& Winner & Loser \\
Amount realized & $\$ 300$ & $\$ 0$ \\
Basis & 100 & 100 \\
\cline { 2 - 3 } Gain (loss) & 200 & $(100)$ \\
Tax (refund) & 100 & $(50)$ \\
After-tax proceeds & 200 & 50
\end{tabular}

Each has chosen an expected after-tax investment return with a mean of $\$ 125$ and a standard deviation of $\$ 75 .^{.8}$ Assume that one wins and the other loses, so that the amounts above are the actual results for the two investors.

What will be the result if a consumption tax is substituted for an

56. Some variant of this latter alternative is a feature of most comprehensive proposals for personal consumption taxation. See, e.g., MEADE REPORT, supra note 4, at 175-83; Consumption Tax, supra note 1, at 1154-60. BLUEPRINTs refers to it as a "prepayment" option because the taxes due on disinvestment are, in effect, prepaid by the denial of a deduction for the amount of the investment at the time that the investment was made.

57. The conclusions that follow would not change if any other allocation were made between risky and riskless investments.

58. "Standard deviation" is the square root of the sum of the squared deviations from the mean, divided by the number of observations. See M. HaMburg, Statistical ANalysis For Decision-Making 189 (1970). Because the after-tax win $(\$ 200)$ and loss $(\$ 50)$ positions both deviate from the mean by $\$ 75$, the deviation in each case is also the standard deviation. 
income tax? That will depend on whether taxpayers will change their investment behavior in response to the imposition of a different tax. We shall assume first that they do not, and then that they do. The second is the better assumption, but its implications are more easily understood after examining the results under the first. Under either assumption the asserted equality of treatment of equally endowed taxpayers will be shown to require acceptance of an ex ante perspective.

Assuming first that the wage earners will continue under the consumption tax their previous practice of investing their entire after-tax wages in the risky asset, the following table shows the results that will obtain and compares them with those under the income tax:

TABLE II

Consumption Tax

Qualified Account Prepayment

Alternative Alternative Income Tax

$\begin{array}{lccc}\begin{array}{l}\text { Investment } \\ \text { Taxpayer A }\end{array} & \begin{array}{c}\$ 00^{\mathrm{a}} \\ \text { Taxpayer B }\end{array} & \begin{array}{r}\$ 100^{\circ} \\ 100^{\circ}\end{array} & \begin{array}{r}\$ 100^{\mathrm{b}} \\ 100^{\mathrm{b}}\end{array} \\ \begin{array}{l}\text { Consumption } \\ \text { A (Winner) }\end{array} & & \\ \quad & & \\ \quad \text { Gross Return } & 600 & 300 & 300 \\ \text { Tax (50\%) } & 300^{\circ} & 0 & 100^{\mathrm{a}} \\ \text { Net Consumption } & 300 & 300 & 200 \\ \text { B (Loser) } & & & \\ \text { Gross Return } & 0 & 0 & 0 \\ \text { Tax (50\%) } & 0 & 0 & \mathbf{5 0} \\ \text { Net Consumption } & 0 & 0 & 50\end{array}$

${ }^{2} \$ 200$ of wages minus zero taxes due to $\$ 200$ investment.

b $\$ 200$ of wages reduced by $50 \%$ tax.

c $50 \%$ of $\$ 600$.

d $50 \%$ of $\$ 200(\$ 300-\$ 100)$

$\cdot 50 \%$ of $\$ 100$ loss $(\$ 0-\$ 100)$

Under the prepayment (or wage tax) alternative, $A$ and $B$ pay taxes of equal present value, $\$ 100$. But how can it be said that their after-tax consumption ( $\$ 300$ for $A$, zero for $B$ ) is of equal present value? The only perspective from which they are equally treated is $e x$ ante, as of the instant before the gamble, with all differences between the winner and the loser ignored. That perspective is natural under the prepayment alternative: $A$ does not pay more taxes than $B$ even though $A$ wins and $B$ loses because no account is taken of changes in the positions of $A$ and $B$ subsequent to the receipt of wages.

At first glance, it might appear that the qualified account alterna- 
tive-the usual consumption tax treatment of deducting investments and including disinvestments-does take the differences in their positions into account, because $A$ pays $\$ 300$ in taxes while $B$ pays none. The apparent difference is illusory, however. The amounts gambled and won under this alternative are in pretax dollars, carrying with them an implicit tax liability, whereas under the prepayment alternative the amounts gambled and won are in after-tax dollars. When $A$ wins $\$ 600$ on qualified account, he receives only $\$ 300$ in potential consumption, coupled with an unavoidable $\$ 300$ tax liability. Likewise, B's $\$ 200$ pretax loss involves the loss of only $\$ 100$ in after-tax consumption. Thus the after-tax results under the qualified account alternative are the same as those under the prepayment alternative: $\$ 300$ in consumption for $\mathrm{A}$, and none for $\mathrm{B}$. The ex ante infirmity that afflicts the latter is, upon reflection, equally damaging to the former.

The life-cycle analysis is necessarily $e x$ ante and defective if outcomes are considered relevant, because the differences between gainers and losers on risky investments are ignored. As the table shows, the income tax taxes winners more heavily than losers. The differences between winners and losers are, after all, gains and losses, which is precisely what the Haig-Simons definition is designed to identify.

The foregoing analysis assumed that taxpayer pretax behavior-here, the investment of all available wages in the risky asset-remained unchanged under the various taxes. The theory of investor behavior under uncertainty is not one on which there is universal agreement, but it seems more reasonable to assume that taxpayers are motivated by the after-tax return on their assets. Investors will accordingly modify their portfolios to take into account the effects of applicable taxes. For purposes of simplicity, let us assume that taxpayers are motivated in investment decisions by the relationship between the mean and deviation of the possible after-tax outcomes.

On that assumption, substitution of a consumption tax for the income tax would not necessarily lead each of our wage earners to invest his entire wages in the risky asset, because that would increase the standard deviation and mean of expected after-tax returns to $\$ 150 .^{59}$ If each investor wanted to maintain an after-tax standard deviation of $\$ 75$ under the consumption tax (as under the income tax), he would invest the tax savings from deducting investments in the riskless asset. In effect, such an investor could purchase all the risk he wanted with a

59. As indicated in Table II, the winner would receive $\$ 300$ and the loser zero. 
$\$ 100$ after-tax investment; had a greater deviation been desired under the income tax, he could have borrowed at the riskless rate to purchase more of the risky asset. Given these assumptions, each investor would put $\$ 100$ in the risky asset and $\$ 100$ in the riskless asset on qualified account; each would also divide his portfolio evenly on prepayment account, $\$ 50$ to the risky asset and $\$ 50$ to the riskless asset, yielding the following results:

\section{TABLE III}

\begin{tabular}{cccc}
\multicolumn{2}{c}{ Qualified Account } & \multicolumn{2}{c}{ Prepayment } \\
Winner & Loser & Winner & Loser \\
$\$ 300$ & $\$ 0$ & $\$ 150$ & $\$ 0$ \\
110 & 110 & $\frac{55}{205}$ & $\frac{55}{55}$ \\
$\frac{110}{410}$ & $\frac{110}{55}$ & 0 & 0 \\
205 & 55 & 205 & 55
\end{tabular}

Amount realized on risky asset Amount realized on riskless asset Taxable consumption $\operatorname{Tax}(50 \%)$ After-tax proceeds 205

Once again, the supposed equality of treatment for equally endowed taxpayers requires adoption of an ex ante perspective. The winner and loser have identical taxes- $\$ 100$ each on wages of $\$ 200-$ only under the prepayment alternative; only their expected consumption in Year 1 is equal under either alternative. The example is, of course, intended to illustrate, rather than demonstrate, the results of investment decisions under uncertainty. ${ }^{60}$ The important conclusion for our purposes is that the endowment analysis requires an ex ante perspective, whether investors are thought to maintain or change their pretax investment behavior in response to changes in the tax base.

\section{b. The Consumption Tax and the Exclusion of Riskless Return}

The assumption that investment behavior depends on expected aftertax results suggests another argument for the consumption tax; it produces results that are essentially equivalent to those of an income tax that exempts the riskless return on all invested assets, regardless of the risk of the actual investment and the actual return. In the example discussed above, each investor has $\$ 100$ to invest under the income tax

60. The mean in this case would be $\$ 130$, rather than $\$ 125$, as under the income tax. If the investors wished to maintain that mean under the consumption tax, they could invest $\$ 125$ in the riskless asset and $\$ 75$ in the risky asset, in which case the standard deviation would be $\$ 56.25$. Relative to the income tax, the consumption tax would thus permit the investor to decrease the deviation while maintaining the mean, increase the mean while maintaining the deviation, or obtain some intermediate solution. No matter which of these alternatives was actually chosen under the consumption tax, the conclusion in the text-that equality of treatment requires an ex ante perspective-would apply. 
in Year 1; if the riskless return were excluded on the amounts invested in all assets, the results would be as follows:

TABLE IV

$\begin{array}{lcc} & \text { Winner } & \text { Loser } \\ \text { Amount realized } & \$ 300 & \$ 0 \\ \text { Basis } & 100 & \frac{100}{(100)} \\ \text { Gain (loss) } & 200 & (10) \\ \text { Exclusion of riskless return } & (10) & (110) \\ \text { Taxable income (loss) } & 190 & (55) \\ \text { Tax (refund) } & 95 & 55 \\ \text { After-tax proceeds } & 205 & \end{array}$

The expected investment return under this limited income tax continues to have a standard deviation of $\$ 75$, but it now has a mean of $\$ 130$. Thus the limited income tax results in an increased mean and an extra $\$ 5$ received by both the winner and the loser, as compared with the results under a comprehensive income tax. This difference is due to the effective exclusion from the tax base of the riskless rate of return. The exclusion permits the taxpayer to invest in his preferred portfolio without the reduction of mean return that occurs under the standard income tax even if the riskless asset is chosen.

As a comparison of Table III and Table IV shows, the consumption tax reaches the same result as a limited income tax in this example. ${ }^{01}$

61. The equivalence can also be illustrated with simple algebra. Consider a two-period model in which wages (w) are earned in period 1 . All after-tax wages are invested, a fraction $(a)$ in a risky asset yielding $x$ rate of return, the remainder $(1-a)$ in a risk-free asset with rate of return $r$. Period 2 after-tax consumption under a flat rate $(t)$ consumption $\operatorname{tax}(\mathrm{CT})$ is as follows:

$$
(1-t) w+(1-t) w a x+(1-t) w(1-a) r
$$

The limited income tax (LIT) to be compared is a standard income tax (IT) with a deduction for the risk-free rate of return $(r)$ on net invested assets $[(1-t) w]$, which deduction is worth $(1-t)$ wrt to the taxpayer in period 2. Under the behavioral assumption that the investor will adjust his pretax investment behavior in order to obtain the same aftertax result under different taxes, the taxpayer will invest a larger portion of his net wages in the risky asset under the IT or LIT than he did under the CT. Since the investor is willing to invest $a w$ in the risky asset under the CT, he can obtain the same after-tax results under the LIT, where he has only $(l-t) w$ to invest, by allocating $a / 1-t$ to the risky asset, leaving $(1-(a / 1-t))$ for the riskless asset. Period 2 consumption under the LIT is then:

$$
\begin{aligned}
& (1-t) w+(1-t)^{2} w x a / 1-t+(1-t)^{2}(1-(a / 1-t)) w r+(1-t) w r t \\
& \text { or } \\
& (1-t) w+(1-t) w a x+(1-t)[(1-t)-a] w r+(1-t) w r t \\
& \text { or } \\
& (1-t) w+(1-t) w a x+(1-t) w(1-a) r
\end{aligned}
$$

Now suppose that all funds $(w)$ are invested in the risky asset under the CT, so an investor under the LIT can reach the same result only by borrowing $t w$ at an interest 
The equivalence of a flat-rate consumption tax with a flat-rate limited income tax under these circumstances suggests that the difference between the income and consumption bases for personal taxation is not as great as is often suggested. ${ }^{62}$ Indeed, the equivalence suggests that the case for the consumption tax could be stated as a case for exempting only the riskless return on invested assets from the income tax. ${ }^{63}$

What would be the justification for such an exemption? The Treasury Department has suggested that "much of what is generally labelled capital income is really a reward for postponing immediate consumption of past wages." ${ }^{4}$ If this view were accepted, it might be argued that the riskless rate of return somehow compensates all investors for the pain of deferring their consumption-but that justification leads back to the realm of psychic benefits and detriments rejected above. One might as well argue for excluding wages as merely offsetting the pain of working.

An alternative argument for exempting the riskless rate of return from the income tax would be acceptance of the Fisherian analysis for certain, but not uncertain, investment return. That view, which was rejected above, would be entirely consistent with a consumption tax that differed in after-tax result from an income tax principally in the effective exemption of riskless investment return.

rate $r$. Period 2 consumption under the $\mathrm{CT}$ is:

$$
(1-t) w(1+x)
$$

Under the LIT, period 2 consumption would be:

$$
\begin{gathered}
(1-t) w+(1-t)^{2} w x+(1-t) t w x-(1-t) r t w+(1-t) t w r \\
\text { or } \\
(1-t) w[1+\underset{\text { or }}{(1-t) x+t x]} \\
(1-t) w(1+x)
\end{gathered}
$$

62. See Warren, supra note 1 , at $938-41$ (arguing that a consumption tax is equivalent to a tax only on wages under certain conditions).

63. On this view, the consumption tax and the limited income tax differ from a standard income tax in that only the latter reaches the return to riskless assets. All three taxes reach wages and returns not associated with risk-taking, such as pure windfalls from lucky opportunities that could not be expected. As to differences in the treatment of returns to risk-taking under the income and consumption taxes, see N. KaLdoR, supra note 5, at 102-29 (suggesting that income and consumption taxes will have different effects on risk-taking); Brown, Mr. Kaldor on Taxation and Risk Bearing, 25 REv. Econ. Stud. 49, 52 (1957) (concluding that effects will be the same); Shoup, Effects of Sales Taxation on Risk-Taking, in FinANZ- UND GeLDPOLITIK IN UMBRUCH 237 (H. Haller \& H. Recktenwald eds. 1969) (suggesting that general sales tax has the same effect on risk-taking as an income tax, although it differs from income tax in that there may be different results in different industries).

64. BLUEPRINTs, supra note 3 , at 136 . 


\section{c. Graduated Rates}

If all assets returned income at the same certain rate, equality of present value among equally endowed taxpayers consuming in different years could be maintained under a system of lifetime cumulative averaging even with graduated consumption tax rates. ${ }^{65}$ Consumption from the current period would be added to that of prior periods, increased by the standard rate of return; graduated rates would be applied to the sum, and a tax credit given for tax paid in prior periods, again increased by the standard rate of return. Because there would be only a single rate of return, equivalent results would obtain under the prepayment and qualified account alternatives. If, therefore, the ex ante view were embraced, that view would be as applicable to graduated taxes as it was to flat-rate taxes, as long as investment return were certain.

However, once uncertainty is introduced, as it must be to reflect real investment results, cumulative averaging under the qualified account alternative with graduated rates will not accomplish equal treatment of equally endowed taxpayers, even given the ex ante perspective. There is simply no way each taxpayer's taxes could be increased at the individually appropriate rate. Taxpayers whose investments returned larger gains would have greater lifetime consumption and consequently pay higher lifetime taxes. Nor would there be equivalence of treatment between the prepayment and qualified account alternatives. The endowment rationale thus argues either for flat rates, so that no averaging is necessary, or for progressive taxation of wages, coupled with lifetime averaging. Only by completely excluding capital income from a graduated tax can the rank order of individuals achieved by discounting earnings be maintained when investment return is not certain. Instead of achieving equal treatment of equally endowed taxpayers, cumulative averaging of uncertain investment return under a qualified account consumption tax would simply extend the standard-ofliving rationale from a single year to the taxpayer's entire lifetime. Like the income concept, which could also incorporate cumulative lifetime averaging, ${ }^{66}$ that rationale requires an ex post perspective.

In summary, the life-cycle view is subject to the same objection as the Fisherian analysis-that it is necessarily ex ante, rather than ex post-whether certain or uncertain investment return is considered.

65. See W. VickreY, supra note 5, at $172-97$ (discussion of cumulative averaging, which is intended to make the income- or consumption-tax burden independent of the distribution of income or consumption over the taxpayer's lifetime).

66. Id. at 172-95. 
Moreover, even if the ex ante perspective is accepted as appropriate, graduated rates make the equal treatment of equally endowed taxpayers impossible under standard, qualified account consumption tax treatment if investment return is not certain..$^{67}$

\section{Income: An Inherently Defective Concept}

In addition to arguments that an income tax base is less fair than a consumption tax base, the case for consumption taxation has included the proposition that an income tax is necessarily inequitable because income is an inherently defective concept that cannot be rationally elaborated.

\section{a. Capital Gains}

The principal argument that income is impossible to define, even in theory, offered by Nicholas Kaldor in his influential book, $A n E x$ penditure Tax, is that the income concept cannot properly measure capital gains that are due to changes in the interest rate. ${ }^{68} \mathrm{Kaldor}$ com-

67. Professor Martin Feldstein has used the lifetime view in a somewhat different way to argue that the Haig-Simons principle conflicts with the notion of horizonal equity implied by economic theory. He concludes that if there is anything to be learned from utilitarianism about the equity of alternative tax bases, a tax on consumption or labor income is preferable to a tax on total income. Feldstein, supra note 2, at S37-38; see Feldstein, On the Theory of Tax Reform, 6 J. Pub. Econ. 77, 86-89 (1976).

The crux of Professor Feldstein's argument is that accretion reaches only income and not other possible sources of utility, such as effort, leisure, or prestige. Because these other items are left out of the accretion equity accounting, they may also be left out of the consumption equity accounting. But once they are removed, utility realistically depends on income only in a very short period; over a longer period it is dependent on consumption, so utilitarianism mandates taxation of consumption, not income.

This argument avoids the defects in the endowment argument pointed out in the text, see pp. 1101-05 supra, by reasoning to a conclusion in which the individuals under comparison have precisely the same consumption path, so that the difficulty of comparing equal earners who consume in different periods does not exist. The argument does not suggest that consumption taxation complies strictly with the utilitarian formulation of horizontal equity; rather, it simply indicates that if utility depends only on consumption, the consumption tax is superior. The conclusion of the argument also depends on the premise that the case for the income tax assumes equal tastes. Identical tastes might well be assumed for effort, leisure, and prestige under the Haig-Simons concept, with differences in tastes for present and future consumption permitted. In that case, individuals with the same present value of income may well have different consumption paths. If they, nevertheless, have the same utility level, then Professor Feldstein's argument for a flat-rate wage or consumption tax reduces to the argument presented in BLUEPRINTs, supra note 3: it depends on an equality of present value or endowment ex ante, and is subject to the same objections raised above. Progression, on that view, would again support a graduated wage tax rather than a graduated consumption tax on qualified account.

68. N. KALDOR, supra note 5, at 44-46, 69-70. Kaldor's other arguments on the grounds of theoretical inconsistency are, as he concedes, arguments against defects in the then cxisting system of taxation in the United Kingdom, not arguments against an income tax free of such defects. Thus, the proposition that wealth, as well as income, is a source of 
pares increases in asset values that arise from increases in the expected income-stream produced by an asset with increases in asset values that arise solely from a change in the interest rate at which an unchanged income-stream is discounted. While the latter involves an increase in "spending power" due to the increased capital value, it is said to be inferior to a capital gain of the former type, which involves an increase in spending power even if the capital asset is not sold, because the annual income produced by the asset will be increased. Since there is no adjustment, even in theory, that could account for this difference in spending power, there is supposedly no way in which the concept of income can correctly treat these two very different kinds of capital appreciation.

Kaldor's argument may be illustrated as follows. If $\$ 10,000$ is invested in a perpetual bond yielding ten percent, the bondholder will receive $\$ 1,000$ annually in interest. If the interest rate subsequently falls to five percent, the capital value of the bond will increase, other things being equal, to $\$ 20,000$; the bondholder will continue to receive $\$ 1,000$ annually so long as he retains the bond. It is the fact that retention of the bond will not generate increased cash flow-and additional consumption possibilities-that supports the conclusion that the increase in current value cannot be considered taxable income. Yet the bondholder is certainly better off, even if he does not sell the bond, than a second bondholder who did not invest in this asset until after the decline in the interest rate. The first bondholder will receive twice as much each year as will the later bondholder, since the latter will receive only $\$ 500$ annually from his $\$ 10,000$ investment at five percent.

The conclusion that the Haig-Simons definition reaches the conceptually correct results in these cases is reinforced by considering another example. Suppose $\$ 10,000$ is invested in a parking lot that produces $\$ 1,000$ yearly in net income. Due to the unexpected construction of a nearby casino, the yearly income from parking doubles to $\$ 2,000$, so that, other things being equal, the capital value of the parking lot also doubles to $\$ 20,000$. The Haig-Simons definition would

\footnotetext{
"spending power," id. at 31-33, is an argument for enactment of a wealth tax, not for repeal of the income tax. And the concern that some receipts should be treated differently from others under a progressive tax because they are bunched into a single period-and may not be repeated-id. at 34-35, leads to the conclusion that some sort of averaging is appropriate under an income or consumption tax, not that the income concept is defective. The inconsistent exclusion of particular kinds of receipts, id. at 35-37, suggests that the income tax would be better if the tax base were comprehensive, not that a comprehensive income tax is undesirable. Finally, the need to adjust the taxation of capital income for inflation, see id. at $42-43$, is in theory soluble by indexing the basis of assets and liabilities.
} 
require inclusion of the $\$ 10,000$ increment in income. When the parking lot owner receives $\$ 2,000$ in income each year, he will be taxed on twice what the first of the foregoing bondholders receives $(\$ 1,000$ in interest), leaving the taxpayers in their correct relative positions in terms of market value: the parking lot owner has a gain on his investment as well as additional annual cash flow; the first bondholder has a gain on his investment, but no more cash flow than he expected; and the second bondholder has no gain, and only his expected cash flow. To indicate that some market value-Kaldor's "spending power"-is more relevant than others is only to assert that spending-here cash flow-may be a better tax base than income, not that income is somehow a defective concept.

Notwithstanding the fact that a short-term investor (such as the later bond purchaser above) receives no deduction for the loss he suffers by holding cash when interest rates are falling, it has been argued that the investor who takes a long position should not be taxed on his gain, because his position relative to the short-term investor will be adequately reflected by the fact that his investment is earning interest at a greater rate than the short-term investor's. ${ }^{\circ 9}$ This view would again seem to depend on a Fisherian view of.income as consumption; it does not, in any event, suggest that the accretion result is impossible to elaborate, even in theory. Imagine an investor who purchases a one-year bond for $\$ 10,000$ at the end of Year 1 , when the interest rate is ten percent, so that he will receive $\$ 1,000$ in interest at the end of Year 2 as well as his $\$ 10,000$ principal. If the interest rate falls immediately to five percent, the value of his bond will increase by $\$ 476.18$ as shown in the following table:

\begin{tabular}{lcc} 
& TABLE V & \\
Due in 1 year & Present Value & Present Value \\
$\$ 10,000$ principal & At 10 Percent & At 5 Percent \\
$\$ 1,000$ interest & $\$ 9090.91$ & $\$ 9523.80$ \\
Total & 909.09 & 952.38 \\
\hline $10,000.00$ & $\$ 10,476.18$
\end{tabular}

An investor who purchased the bond after the change in interest rates would have to pay $\$ 10,476.18$ for the right to receive $\$ 11,000$ in Year 2 .

The Haig-Simons concept would tax the first investor on $\$ 476.18$ in Year 1 and both investors on $\$ 523.82$ in Year 2 (\$11,000-\$10,476.18).

69. See Consumption Tax; supra note 1, at 1144. Although Professor Andrews does not discuss losses, presumably he would also conclude that the loss incurred by a bondholder when interest rates increase should not be taken into account. 
Taxing both investors only on their interest in Year 2 would achieve the same total tax, but in different years:

TABLE VI

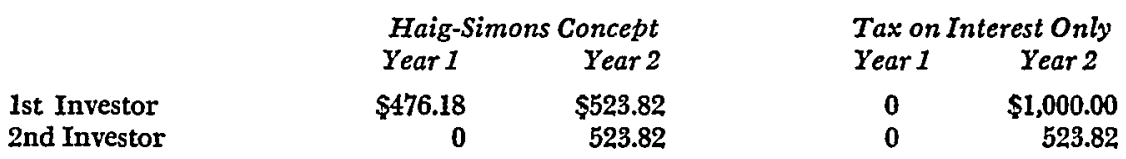

The argument that taxing only the interest adequately accounts for the differences between the two investors depends on the consumption-tax premise that economic return should not be taken into.account until consumed, whereas the result under the Haig-Simons concept reflects the fact that, in Year 1, the first investor has experienced a market gain relative to the second investor and that they are in identical positions thereafter. Relying only on the difference in interest received to reflect difference in position would require treatment that is just backwards in terms of market value, the touchstone for income taxation: the taxpayers would be treated identically when their positions differ in Year 1 , and differently when their positions are the same in Year 2.70

70. As is traditional in accretion analysis, attention up to this point has been focused on assets, leaving liabilities totally out of account. But the bond transaction discussed above involves a borrower as well as a lender. If we assume that this loan functioned solely to permit the borrower to consume $\$ 10,000$ in Year 1 instead of $\$ 11,000$ in Year 2, no new social product would be created thereby, with the result that Haig-Simons income in Year 1 would appear to exceed social product by $\$ 476.18$. There is, however, an offsetting loss in this case: the precisely equivalent diminution in value experienced by the borrower when the interest rate declined from $10 \%$ to $5 \%$. Prior to that moment, the borrower could have discharged his liability by paying the lender $\$ 10,000$; once the interest rate declined, however, the creditor would discharge the liability, by selling the bond to the issuer, only on receipt of $\$ 10,476.18$, the market price of the bond.

Although liabilities have not been much discussed in the context of a comprehensive income tax, such a tax would necessarily take into account changes in what has been called the "anti-value" of liabilities, as well as changes in the value of the corresponding asset. W. Barnett, Note on Accounting for Transactions in Liabilities (unpublished manuscript on file with Yale Law Journal). The income tax now in effect, which is triggered by realization events, should require inclusion of the offsetting gain and permit deduction of the offsetting loss if realized. Transfer of $\$ 10,476.18$ from the borrower to the lender in cancellation of the obligation should give rise to $\$ 476.18$ in income to the lender as the excess of amount realized over basis and a $\$ 476.18$ deduction to the borrower as the excess of amount paid over the amount received. See, e.g., Commissioner v. Sisto Financial Corp., 139 F.2d 253, 255 (2d Cir. 1943); EIverson Corp. v. Helvering, 122 F.2d 295, 297 (2d Cir. 1941); Treas. Reg. $\$ 1.163-3$ (c) (1979).

Thus far, only the effect of interest rate changes on debt instruments has been discussed, but the value of equity assets may also change with interest rates. Consider a taxpayer $A$ who buys an asset-say, another parking lot-that will provide $\$ 100$ in annual asset-services-in this case, parking spaces-in perpetuity. At a discount rate of $10 \%, A$ will pay $\$ 1000$ for the asset, which will be worth $\$ 2000$ if the discount rate at once falls to 5 percent, yielding an immediate gain of $\$ 1000$ in Year 1 . Again, where is the offsetting loss that is necessary if Haig-Simons income is to equal social product? The in- 


\section{b. Human Capital}

A second theoretical defect that is said to inhere in the concept of income is its inability to deal with investments in "human capital." 11 An individual who invests part of his wages in the stock market or in real estate must invest after-tax dollars because wages are subject to the income tax. Similarly, a person who saves, that is, does not realize, the appreciation in value of corporate securities or real estate would have income under the Haig-Simons concept, although the realization criterion would preclude taxation under current law until the appreciated assets were sold or otherwise disposed of.

What then is the proper treatment of a taxpayer who forgoes several years of wages to attend professional school in order to increase his lifetime earnings? And what of the taxpayer who possesses a significant earning capacity due to some innate ability that is greatly valued in the marketplace? Finally, what of shifts in market valuations of an individual's ability, whether innate or developed?

Critics of the concept of income argue that all of these individuals possess human capital, which should in theory be treated by the HaigSimons concept like all other capital investments. Thus the professional school student should be treated like the wage earner who invests in the stock market: forgone wages should be imputed to the student, as should a corresponding investment in educational capital. ${ }^{72}$ To do otherwise, the argument runs, would be to permit investments in human capital to be made out of pretax dollars, while other investments must be made out of after-tax dollars. In realization terms, investment in human capital on this view is currently expensed (that is, deducted) in the year made if the investment involves forgoing wages, whereas other capital expenditures must, of course, be capitalized and recovered on sale or through depreciation or depletion deductions over the life of the asset. Similarly, the individual who has an innate ability to play basketball or to pick successful television shows has at some point in

crease in asset-value depends on a continuation of the previously expected return of $\$ 100$ annually in asset-services; by hypothesis, there must be a taxpayer (or group of taxpayers) $B$ who will continue to pay $\$ 100$ annually for the asset-services. Although the fall in interest rates has not affected the annual rentals $B$ must pay $-\$ 100$ in perpetuity-the present value of that stream of future payments has grown from $\$ 1000$ to $\$ 2000$. Thus the antivalue of $B$ 's implicit obligation has grown by precisely the same amount that the value of the asset (which depends on the existence of the implicit obligation) has risen, so $A$ 's gain is just offset by $B$ 's loss.

71. See Meade Report, supra note 4, at 39-40; Klein, supra note 1; Consumption Tax, supra note 1 , at $1145-46$.

72. A fortiori out-of-pocket expenditures should be capitalized. See McNulty, Tax Policy and Tuition Credit Legislation: Federal Income Tax Allowances for Personal Costs of Higher Education, 61 CALIF. L. Rev. 1, $14-36$ (1973). 
his life acquired significant human capital, which is an increment in wealth that should in theory be subject to taxation under the HaigSimons concept. Finally, shifts in market valuation of various skills should presumably be recognized in the calculation of taxable income.

The logical implication of these results is that individuals would in theory be taxed on changes in the present value of what they could earn, quite apart from what they do earn. Yet the idea of any tax on earning capacity is inconsistent with widely accepted concepts of individual liberty because it would disregard such personal choices as which career to pursue, the amount of time to devote to work as opposed to leisure, and so on. ${ }^{73}$ Consumption-tax advocates have thus concluded that the concept of income is not capable of rational elaboration in our society. ${ }^{74}$ Apparently that conclusion would also apply to a comprehensive wealth tax applied during the taxpayer's lifetime, since human capital would presumably have to be included in such a tax base if logic required increments in such value to be reached by the income tax.

There are at least two possible responses to these concerns. The first is that the logical implication of the concept of income is indeed that human capital should be treated like other capital, so that in theory invested imputed income should be taken into the tax base, just as in theory imputed income that is consumed should arguably be taken into account. ${ }^{75}$ Then, as in the case of consumed imputed income, the relevant issue becomes whether practical considerations preclude the taxation of such income. But even if this aspect of the concept of income were thought incapable of practical application, that would not establish that there was anything logically defective about the concept or the tax on incremental earning capacity that it would support. Rigorous as such a response might be, however, it is not very convincing, given the general institutional bias in our society against slavery and other means of permitting the realization of a market value for human capital.

The existence of that bias provides the ground for the second, and

73. Kelman suggests that, apart from this libertarian defect, a capacity tax "may be the ideal measure of ability to pay ... might best achieve the tax system's goal of measuring the inequality of economic power ... [and] might also best assess the sacrifices a particular taxpayer is making when he is asked to give a certain sum of money to the state." Kelman, Personal Deductions Revisited: Why They Fit Poorly in an "Ideal" Income Tax and Why They Fit Worse in a Far From Ideal World, 31 Stan. L. Rev. 831, 841 (1979).

74. Klein, supra note 1 , at 463-69.

75. For a discussion of imputed income that is consumed, see H. Simons, supra note 10 , at 110-122.

\section{4}


preferable, response to this alleged defect in the concept of income. The bias reflects a view that persons cannot be forced to work against their will. Like other capital, human capital embodies a capacity for production, but for reasons of liberty we distinguish human capital with regard to forced production, reflecting the fundamental distinction between an individual and the fruits of his labor mentioned earlier. ${ }^{70}$ Although the matter can be disputed, people may be thought of as distinct from things, even when the things are the product of human endeavor. The individual's personhood may be said to extend to his productive capacity, but not to his product.

The legal system has embraced the distinction between persons and things not only in the prohibition against slavery, but in statutes that prohibit long-term contracts for personal services ${ }^{77}$ and commerce in infants, ${ }^{78}$ as well as in the absence of specific performance as a remedy for breach of a contract to perform personal services. ${ }^{70}$ The fact that the Haig-Simons calculation leaves changes in the value of human capital out of account is but another iteration of the same distinction.

Moreover, legal constraints deprive human productive capacity of significant marketable capital value in most cases. There is simply no way a medical school graduate can cash in on the high income potential of an M.D. without working as a physician. To be sure, a lending institution is likely to lend more to such a graduate than it would to a young artist with only a meager prospect. But no lender is very likely to extend credit even to an M.D. beyond the amount of a few years of salary, unless other security is provided. Indeed, the inability of a person in our society to become an indentured servant or to sell himself into slavery calls into question the very label of human "capital" in these cases. It is true that by discounting a stream of future earnings, the value of a prospective earnings pattern can be "capitalized," but if there is no way in which that capitalized value can be used currently to command economic resources, why should it be counted as part of the "store of property rights" in the Haig-Simons calculation?

76. See pp. 1096.97 supra.

77. See, e.g., LA. Civ. Code ANN. art. 167 (West Supp. 1978) ("Persons who have attained the age of majority cannot bind themselves for a longer term than ten years."). Even in the absence of statutory prohibition, the common law has been hostile to such contracts. See J. Calamari \& J. Perillo, Contracts 47.48 (2d ed. 1977); 3A A. Corbin, Contracts $\$ 684$ (1960 \& Supp. 1971).

78. See, e.g., 18 PA. Cons. Stat. ANN. $\$ 4305$ (Purdon 1973) ("A person is guilty of a misdemeanor of the first degree if he deals in humanity, by trading, bartering, buying, selling, or dealing in infant children.")

79. See J. Calamari \& J. Perillo, supra note 77, at 585-87; 5A A. Corbin, supra note 77, § 1204 (1964 \& Supp. 1971). 
For some individuals there is, of course, a significant market value to their services that can be realized in a guaranteed capital amount. An outstanding professional athlete may be able to trade his production for future years for a large sum of money, which he will receive even if he is injured and cannot perform. In fact, if the relevant period is short enough, most taxpayers can anticipate the return on their future labor by sale or hypothecation. But even when a value can be so obtained, the rights of the purchaser or lender are not the same as those obtained when goods are involved. If the professional athlete fails to perform, he cannot be forced so to do, even though the delivery of goods sold under a contract might be required. If an individual has borrowed against future earnings, which he fails to receive because he declines to work, the lender cannot foreclose on the borrower's productive capacity and operate it to regain his loan proceeds. The legal rules reflect a physical as well as philosophical difference between goods and personal services: goods can be forcefully separated from their owner with relatively little effort, as compared with forcing an individual to work against his will.

A different way of putting the legal point is that unlike the marketing of goods, the sale or hypothecation of future services does not really involve the transfer of services, but only of the right to claim damages if they are not later transferred and, in some cases, the right to prevent transfer to another buyer. In terms of the distinction between persons and things, a legal education is inherently a part of the lawyer's person, unlike his possessions or product. Whether income from personal services can be anticipated or not, human capital thus has a legal status fundamentally different from that of other capital, so that the different treatment accorded it by the income tax is not at all illogical.

Stating the point yet another way, the concept of human capital is not helpful in defining the income tax base, because the concept is entirely an ex ante formulation when there is no market mechanism for realizing the value of the capital. While the human capital amount that is arrived at by summing the present value of future income streams has had a great impact on economic theory ${ }^{80}$ and is undoubtedly useful for some purposes-such as deciding whether to go to professional school in order to increase lifetime earnings-that amount is not germane to the interpersonal calculation of the income tax base, which

80. See Sahota, Theories of Personal Income Distribution: A Survey, 16 J. EcON. LITERATURE 1, $11-19$ (1978). 
concerns changes in power to command goods and services in the marketplace. 81

\section{c. Conceptual Incoherence}

Whatever the particular treatment of capital gains and human capital, income also has been rejected as a generally incoherent concept for purposes other than taxation. These well-known objections to the idea of income do not, however, undermine its appropriateness as a tax base. Three different versions of conceptual incoherence can be identified.

First, income has been rejected in economic and accounting analysis because the concept includes not only gains that were, or should have been, anticipated to some extent, but also totally unexpected windfalls. ${ }^{82}$ Such unanticipated changes in position are irrelevant to the economist, who seeks to explain behavior based on what individuals know about the future. An accountant reporting on the stewardship of management in order to provide a sound basis for investment decisions, and a financial analyst seeking to maximize future wealth, would also find such unanticipated changes irrelevant. Accordingly, economists and accountants have attempted, without great success, to develop concepts of income that omit such windfall gains and losses. ${ }^{83}$ In addition,

81. As in the case of changes in the rate of interest, it should be inquired whether the view taken here of human capital is consistent with the idea of income as product that the Haig-Simons definition allocates among taxpayers. If production of a new machine is regarded as income to be allocated to its owner, why is not the same true of a medical school education? One might respond that the medical-school education is necessarily not a completed asset, because it is not clear that the graduate will work as a physician. But that response leads to the conclusion that a society with more doctors (or lawyers) is no better off than the identical society, save the professional education. The preferable answer seems to me that there is indeed social product, but a product that is not subject to the same market transactions under existing legal rules. Hence the Haig-Simons definition appropriately leaves it out of account when computing personal income.

82. See J. Hicks, Value and Capital 171-81 (2d ed. 1946); N. Kaldor, supra note 5, at 67-69; Solomons, Economic and Accounting Concepts of Income, 36 Accounting REv. 374, 374-83 (1961).

83. See J. Hicks, supra note 82 , at $172-73$ (defining income as "the maximum amount which can be spent during a period if there is to be an expectation of maintaining intact the capital value of prospective receipts ..."). When applied ex post to the actual values of capital at the beginning and end of an accounting period, the result is simply the Haig-Simons formulation. When applied $e x$ ante at the beginning of the accounting period, the definition requires a hypothetical minuend: that is, the value that the capital is expected to have at the end of the period, from which the (known) capital value at the beginning can be subtracted in order to yield the period's income. If applied ex post, but adjusted to eliminate changes in expectations, the definition requires a hypothetical sub. trahend: that is, a revised initial value-as estimated at the close of the period-which may be subtracted from the known value of the capital at the end of the period, in order to yield the period's income. See N. KALDOR, supra note 5, at 62-63; MEADE REPORT, supra note 4, at 31-33 (suggesting and rejecting following definition of taxable income as 
modern financial analysis has emphasized cash flows and fund accounting more than the distinction between income and capital. ${ }^{84}$ For our purposes, however, these concerns and modifications are simply not germane. Economic, accounting, and financial analyses are necessarily concerned with the future. Their orientation is, by hypothesis, ex ante. But for tax purposes, income ex post is what matters, and that concept should include all gains and losses, whether anticipated or not. As argued earlier, distribution of tax burdens should be concerned with what has happened, not with what can be expected.

A second version of the incoherence argument appears as a problem in national-income accounting, which is itself an ex post measure. A nation's production may be defined as the aggregate of the goods and services produced during the accounting period, but disparate physical quantities cannot be meaningfully summed. Accordingly, the national product is computed by summing each good's and service's total market value, the result of multiplying the physical quantity of that good or service by the market price per unit. ${ }^{85}$ But a problem arises when aggregations made at different times (or in different places) are to be compared: since prices and quantities may have changed, how can the sum of quantities with different multiplicands be compared in any meaningful sense? In terms of the Haig-Simons definition, this objection might be framed as follows: how can wealth at the beginning of the period be compared with wealth at the end, when the prices and quantities that are multiplied and summed may be different? ${ }^{38}$

In general, the incomparability of national income aggregates can be resolved by the use of index numbers-the second-period quantities can, for example, be multiplied by the first-period prices, so that comparison in those prices is possible. Alternatively, the comparison can be made with first-period quantities at second-period prices. Such index numbers necessarily yield only approximate (and sometimes dif-

alternative to Haig-Simons concept: amount that individual "could consume in any one year and yet be left with the resources and expectations at the end of that year which would enable him to maintain the same level of consumption indefinitely in the future"); Alexander, Income Measurement in a Dynamic Economy, in STUdY Group ON Business Income, American Institute of Accountants, Five Monographs on Business Income 1, $62-73$ (1950), reprinted in Studies in Accountinc Theory 126, $177-88$ (W. Baxter \& S. Davidson eds., rev'd by D. Solomons 1962) (suggesting use of concept of "variable income" to eliminate such changes in expectation).

84. See, e.g., E. Fama \& M. Miller, The Theory of Finance 58-340 (1972).

85. See R. Stone \& G. Stone, supra note 21, at 11-30. Duplication must be avoided by counting only the value added by each industry, since some products may be used in the production of others.

86. See Samuelson, The Evaluation of "Social Income": Capital Formation and Wealth, in F. Lutz, The Theory of Capital 32, 56 (D. Hague ed. 1961). 
ferent) solutions, so an average of their results may be considered the most accurate comparison. ${ }^{87}$

Whether or not this response to the charge of incommensurability is acceptable for national-income accounting purposes, the charge is irrelevant for tax purposes. The need for index numbers that arises from the national-income accountant's desire to eliminate changes in relative prices does not exist in defining the tax base, which should take into account gains and losses due to changes in relative prices, as well as gains and losses due to changes in quantities. ${ }^{88}$ The comparison under the Haig-Simons concept is of wealth, not product, at two different times. Thus the aggregate value assigned by the market to a particular bundle of rights is the ultimate goal of the inquiry, and not a mere intermediate step leading toward a final calculation of changes in quantity of output. In short, the intertemporal comparison called for by the income tax is quite intelligible, given the use of index numbers in periods of inflation, a modification that is widely understood today. ${ }^{89}$

The last objection to income on the grounds of incoherence, which is also found in the literature of national-income accounting, accepts the ex post approach and the index-number solution to the problem of comparing consumer commodities in two different periods, but argues that aggregation of consumption and accumulation in any single period cannot result in an intelligible amount. ${ }^{90}$ The argument can be stated in conceptual terms, or as following from the purpose of the income measurement. Focusing first on the concepts to be aggregated, consumption and accumulation can be said to be dissimilar, indeed opposite, quantities-the former relating to resources that have been used up (final goods), the latter pertaining to resources that have not (intermediate goods)-so that their sum is not meaningful.91 Under the view of the Haig-Simons definition taken here, that argument is not convincing unless production and product are also to be regarded as incoherent concepts. If those concepts are conceded meaning, then there

87. See R. Stone \& G. Stone, supra note 21, at 95-97; I. Fisher, The Making of Index Numbers (3d ed. 1927).

88. See Hicks, Maintaining Capital Intact: A Further Suggestion, 9 Economica 174, 178 (1942) (suggesting that "depreciation" of assets be distinguished from "capital Iosses" on such assets due to unexpected obsolescence). The Haig-Simons concept would make no such distinction among diminutions in market value. For additional discussion of this issue, see Pigou, Maintaining Capital Intact, 8 Economica 271 (1941); Hayek, Maintaining Capital Intact: A Reply, 8 Economica 276 (1941).

89. See H. Aaron, supra note 29.

90. See Samuelson, supra note 86 , at $44-51$.

91. See Consumption Tax, supra note 1, at 1115 (arguing that consumption and accumulation adjustments to tax-paying capacity differ in a number of ways). 
is nothing incoherent about regarding admittedly different uses of income (or product) as summing to total income (or product).

The alternative version of this argument suggests that the purpose of national-income accounting is the measurement of a society's welfare, and that while consumption and accumulation are valuable indices of such welfare, their sum does not represent a single preferable index because it fails to capture the future welfare that comes from owning capital. ${ }^{22}$ For our purposes, it is enough that consumption is equally defective as a measure of welfare on this view; only a wealthlike magnitude can provide a meaningful single index of such welfare, because only such a magnitude is sufficiently future-oriented. ${ }^{93}$

To summarize, our brief review of the non-tax objections to the concept of income indicates that for many purposes the concept may indeed be an inadequate, and, in some cases, an incoherent idea. But none of those objections leads to the conclusion that the concept of income should be rejected as a tax base because it is inherently defective.

\section{The Consumption Tax and Liberty}

As compared with a tax on personal earning capacity, both the consumption and income taxes are concerned with what an individual chooses to do, rather than with what he might do. Accordingly, it can be argued that both are preferable to a tax levied on capacity because they interfere less with personal choice and liberty. It has been further argued that if taxation of capacity is to be avoided in the interests of liberty, only consumed products should enter the tax base, so the consumption tax is to be preferred to the income tax because the former is levied only when a person chooses to consume. ${ }^{94}$

This argument fails to accept the distinction between persons and things that was given as the reason for not taxing capacity in the case of human capital. ${ }^{95}$ It would seem perfectly plausible to exclude leisure and talents from the tax base on the grounds of personal liberty and at the same time to include economic capacity in the form of unconsumed income; forcing a person to share his income from working is simply not the same as forcing him to work in the first place. ${ }^{96}$

There is, moreover, a sense in which consumption taxation is less consistent with individual freedom than is income taxation. The dis-

92. See Samuelson, supra note 86 , at 51-56.

93. Id.

94. C. FrIED, supra note 39 , at $147-50$.

95. See pp. 1113-17 supra.

96. But see $\mathrm{R}$. Nozick, supra note 43 , at 169 (viewing income taxation as "on a par with forced labor"). 
tributive premise of the consumption tax is that quantitative consumption decisions are for collective, not individual, judgment. It certainly does not seem obvious that this premise shows more respect for individual liberty than does the income tax view that distribution of product is for collective decision. A person's collective responsibilities are concluded at the time of production under the income tax; by contrast, under the consumption tax those responsibilities are not discharged until a person consumes his last resource. It is precisely this inability to escape collective responsibilities by consuming existing resources that has attracted some supporters to the consumption tax in the United Kingdom. ${ }^{97}$

\section{Conclusions and the Relevance of Wealth}

The arguments for the superiority of the consumption tax over the income tax are not convincing even on the terms in which the case has been made-a direct comparison of income and consumption taxes, with the question of wealth taxation put aside for another day.

The Haig-Simons definition of income is best understood as an interpersonal perspective on the measurement of each taxable unit's share of the product of the society's private capital and labor during the accounting period. The equity case for income taxation thus can be premised on society's claim on a portion of that product for redistribution or for the production of public goods. Consumption can also be justified as a criterion of distributional equity, by relating society's claim to standards of living rather than to product. Essentially ex post constructs, either conclusion requires agreement that outcomes rather than expectations are what matter for fairness in taxation.

Much of the recent case for substituting a consumption tax for the income tax depends on the diametrically opposed premise-that expectations alone are relevant. The ex ante view of Fisherian capital theory, while appropriate to economic analysis in general, is not suitable for interpersonal measurement of tax equity, which should be evaluated on an ex post basis. The life-cycle hypothesis, the human capital construct, and the discounting of future consumption to present value in general are therefore not helpful in comparing the two taxes. Nor does the consumption tax appear superior in terms of conceptual coherence or its effect on personal liberty. Nor, finally, do appeals to metaphors such as a common pool or to unknowable levels of psycho-

97. See, e.g., N. KAldoR, supra note 5, at 31-34; MeAde Report, supra note 4, at 33. 
logical satisfaction help to choose between taxes that must realistically be levied on economic resources.

In short, either levy can be justified as fair tax policy in the abstract, with the choice depending on whether the social-product or standardsof-living version of distributive justice can be said to be superior as a matter of political or moral philosophy. In the absence of a clear showing as to that superiority, no choice can sensibly be made between the two taxes-at least as long as wealth is excluded from the comparison.

This indeterminacy suggests that wealth should not be ignored in discussions of the choice of a tax base. ${ }^{98}$ Indeed, the strongest argument in favor of income taxation as opposed to consumption taxation as a matter of fairness is that only income taxation reaches wealth or the return to wealth. ${ }^{90}$ The income tax includes wealth in the tax base from two different perspectives. ${ }^{100}$ On the sources side of the personal income account, income from capital as well as labor is taxed. If all income from all capital were reached, as advocates of a comprehensive income tax base urge, the levy on such income could be considered a proxy for the taxation of the capital itself. On the uses side of the personal income account, inclusion of accumulation means that additions to wealth are taxed each year. The income tax can accordingly be thought of as an incremental tax that reaches the capital amount of all wealth, but only once with respect to each increment to wealth.

Two objections to these reasons for preferring the income tax are at once apparent. First, it is not obvious that wealth should be subject to taxation. Second, if wealth is to be taxed, the base of the consumption tax may be a better proxy than the base of the income tax, especially when existing wealth taxes are taken into account. As to the first point, the argument for wealth taxation on fairness grounds must be that no citizen is entitled to a disproportionate share (however determined) of the benefits of holding wealth. Accumulation itself and not merely its supposed goal of consumption would be made subject to collective decisionmaking on the theory that wealth not only embodies capacity

98. For a recent attempt to introduce the wealth tax into discussions of United States tax policy, see Cooper, Taking Wealth Taxation Seriously, 34 RECORD of THE Ass'N of THE BAR OF THE CITY OF NEW YORK 24, 24-57 (Jan.-Feb. 1979). For a general discussion of the wealth tax, see C. Sandford, J. Willis \& D. Ironside, An Annual Wealth Tax (1975).

99. See Consumption Tax, supra note 1, at 1169; Andrews' Reply, supra note 1, at 957.

100. The precise character of the inclusion of wealth under the income tax appears more elusive when our discussion of risky and riskless assets is recalled. Under certain assumptions, it could be argued that the only difference between the consumption and income tax bases is the treatment of riskless return on invested assets. Even under those assumptions, however, the income tax is arguably preferable to the consumption tax if it is thought that the distributive claim extends beyond wages and windfalls. See pp. 110507 supra. 
for future consumption, but also yields current benefits such as security and independence, which are no more subject to a controlling moral claim by the wealth-holder than are income or consumption. Indeed, such benefits can be conceived of as imputed and consumed income.

One response to this sort of argument for wealth taxation might be that there is no greater reason for collectivizing wealth than there is for collectivizing other forms of security, independence, and power. ${ }^{101}$ If the wealthy investor must share his wealth with less wealthy, should not the talented professional whose wealth is in the form of human capital have to do the same? This argument, like that in favor of measuring and taxing income invested in human capital, ignores the fundamental distinction between persons and things. ${ }^{102}$ If that distinction is accepted, it does not seem inconsistent to set social limits on differences in marketable wealth, and not to set similar limits on other sorts of differences that might be substitutes for such wealth.

Even assuming that wealth provides a plausible basis for a collective claim, there are several shortcomings with the income tax as a proxy wealth tax. ${ }^{103}$ First, previously accumulated wealth would not be taxed currently (although it would have been taxed when accumulated, and current income therefrom would be included in the tax base). Second, tax rates arguably should be graduated on the basis of wealth, rather than on the basis of income or increments to wealth. Finally, at any given level of income, the rich may save less, so a graduated consumption tax might be more progressive with respect to wealth than would be a graduated income tax. Even if the empirical premise in the last argument is rejected, the first two points identify undeniable differences between wealth and income tax bases.

Related to the efficacy of the income tax as a proxy wealth tax is the effect of other taxes reaching capital, such as the estate and gift taxes, state and local property taxes, and the corporate income tax. It might be that given the existence of these other levies, income taxation is not the best means of accomplishing the desired result, particularly if other policies-such as including bequests in a donor's consumption tax base-are considered. ${ }^{104}$

101. This argument would proceed as follows: If wealth is to be taxed because it affords to its holders a substantial measure of security, independence, and power, then other personal holdings-such as a prominent family name, innate physical or mental talents, or personal charisma-that can just as surely provide security, independence, and power should be taxed as well; if we cannot or will not reach the latter, then we should not single out the former for taxation. See Klein, supra note 1, at 467-69.

102. See pp. 1114-15 supra.

103. See Consumption Tax, supra note 1, at 1118-19, 1170-72.

104. See Graetz, Implementing a Progressive Consumption Tax, 92 HaRv. L. REv. 1575, $1624-25$ (1979). 
In short, considerations of wealth raise many issues that cannot be decided by an abstract comparison of the income and consumption bases. Only polar conclusions are possible. If the argument for wealth taxation were completely rejected-perhaps because capacity of any sort were concluded to be too inchoate to support a collective claim, or because the current benefits of holding wealth were rejected as trivialthen the choice for a consumption tax would presumably be clear, since only that tax wholly excludes wealth from the tax base. On the other hand, if wealth were thought to be an appropriate subject for a distributive claim, and if consumption were deemed an inadequate proxy for wealth, then it would be inappropriate to substitute a consumption tax for the income tax without simultaneous enactment of an appropriate wealth tax, whatever that might be.

If the choice to be made were between a consumption tax with some form of wealth or transfer tax and an income tax with or without such taxes, then a decision would not be possible in the abstract. Rather, the choice would depend on the exact components of the two alternative tax packages. The way the issue has been formed by most recent consumption tax proponents-income versus consumption taxation, with the question of wealth taxation put aside for another day-is thus inadequate unless wealth is rejected entirely as a basis for taxation. 